\title{
DGK $\gamma$ Knock-Out Mice Show Impairments in Cerebellar Motor Coordination, LTD, and the Dendritic Development of Purkinje Cells through the Activation of PKC $\gamma$
}

\author{
Ryosuke Tsumagari, ${ }^{1}$ Sho Kakizawa, ${ }^{2}$ Sakiko Kikunaga, ${ }^{1}$ ' Yoshitaka Fujihara, ${ }^{3}$ Shuji Ueda, ${ }^{1}$ \\ Minoru Yamanoue,, ${ }^{1}$ Naoaki Saito, ${ }^{4}$ DMasahito Ikawa, ${ }^{3}$ and ${ }^{D}$ Yasuhito Shirai ${ }^{1}$
}

https://doi.org/10.1523/ENEURO.0319-19.2020

${ }^{1}$ Department of Applied Chemistry in Bioscience, Graduate school of Agricultural Sciences, Kobe University, Kobe 657-8501, Japan, ${ }^{2}$ Department of Biological Chemistry, Graduate School of Pharmaceutical Sciences, Kyoto University, Kyoto 606-8501, Japan, ${ }^{3}$ Research Institute for Microbial Disease, Osaka University, Osaka 565-0871, Japan, and ${ }^{4}$ Laboratory of Molecular Pharmacology, Biosignal Research Center, Kobe University, Kobe 657-8501, Japan

\begin{abstract}
Diacylglycerol kinase $\gamma(\mathrm{DGK} \gamma)$ regulates protein kinase $\mathrm{C}(\mathrm{PKC})$ activity by converting DG to phosphatidic acid (PA). DGK $\gamma$ directly interacts with PKC $\gamma$ and is phosphorylated by $\operatorname{PKC} \gamma$, resulting in the upregulation of lipid kinase activity. PKC dysfunction impairs motor coordination, indicating that the regulation of PKC activity is important for motor coordination. DGK $\gamma$ and PKC are abundantly expressed in cerebellar Purkinje cells. However, the physiological role of DGK $\gamma$ has not been elucidated. Therefore, we developed DGK $\gamma$ knock-out (KO) mice and tested their cerebellar motor coordination. In DGK $\gamma$ KO mice, cerebellar motor coordination and long-term depression (LTD) were impaired, and the dendrites of Purkinje cells from DGK $\gamma$ KO mice were significantly retracted. Interestingly, treatment with the cPKC inhibitor Gö6976 (Gö) rescued the dendritic retraction of primary cultured Purkinje cells from DGK $\gamma$ KO mice. In contrast, treatment with the PKC activator 12-o-tetradecanoylphorbol 13-acetate (TPA) reduced morphologic alterations in the dendrites of Purkinje cells from wild-type (WT) mice. In addition, we confirmed the upregulation of PKC $\gamma$ activity in the cerebellum of DGK $\gamma$ KO mice and rescued impaired LTD in DGK $\gamma$ KO mice with a PKC $\gamma$-specific inhibitor. Furthermore, impairment of motor coordination observed in DGK $\gamma$ KO mice was rescued in tm1c mice with DGK $\gamma$ reexpression induced by the FLP-flippase recognition target (FRT) recombination system. These results indicate that DGK $\gamma$ is involved in cerebellar LTD and the dendritic development of Purkinje cells through the regulation of PKC $\gamma$ activity, and thus contributes to cerebellar motor coordination.
\end{abstract}

Key words: diacylglycerol kinase; knock-out mouse; long-term depression; motor coordination; protein kinase C; Purkinje cells

\section{Significance Statement}

The only output neurons of the cerebellum, Purkinje cells, regulate long-term depression (LTD). LTD and the dendritic development of Purkinje cells are important for motor function. Many studies have revealed functional correlations between signaling molecules involved in the mechanisms of motor coordination; however, we still do not have enough knowledge to understand the overall concept. Here, we show that the functional correlation between diacylglycerol kinase $\gamma(\mathrm{DGK} \gamma)$ and protein kinase $\mathrm{C} \gamma(\mathrm{PKC} \gamma)$ contributes to motor coordination. DGK $\gamma$ regulates the activity of $\mathrm{PKC} \gamma$ which is an important factor in LTD and the dendritic development of Purkinje cells, allowing PKC to function precisely as a mediator of motor coordination. 


\section{Introduction}

Diacylglycerol (DG) is produced by the hydrolyzis of phosphatidylinositol-4,5-bisphosphate $\left(\mathrm{PIP}_{2}\right)$ by phospholipase C (PLC) in response to neurotransmitters, growth factors and hormones. DG functions as a lipid messenger and activator, by binding to several enzymes including protein kinase C (PKC; Almena and Mérida, 2011). DG signaling is terminated by DG kinase (DGK), which phosphorylates DG to produce phosphatidic acid (PA; Sakane et al., 2007). In other words, DGK indirectly inhibits PKC activity by reducing the level of DG. PA is also an important lipid messenger that activates various enzymes including phosphatidylinositol-4-phosphate-5kinase (PI4P5K; Jones et al., 2000), Raf1-kinase (Ghosh et al., 1996), mammalian target of rapamycin (mTOR; Fang et al., 2001), and atypical PKC (Limatola et al., 1994). Therefore, DGK is thought to have important physiological roles in response to different stimuli.

To date, 10 mammalian subtypes of DGK have been identified (Topham and Prescott, 1999; Kanoh et al., 2002; van Blitterswijk and Houssa, 2000). Among them, at least 8 subtypes are expressed in the brain with subtypespecific expression patterns, suggesting subtype-specific functions in neurons (Raben and Tu-Sekine, 2011, Shirai and Saito, 2014). For example, DGK $\gamma$ is abundantly expressed in cerebellar Purkinje cells (Goto and Kondo, 1999; Adachi et al., 2005). However, its function in neurons is still unclear.

Similarly, PKC has 10 subtypes and many of them show subtype-specific expression in the brain. For example, PKC $\alpha$ and $\gamma$ are expressed in cerebellar Purkinje cells (Metzger and Kapfhammer, 2003) and regulate Purkinje cell function, including synaptic plasticity and dendritic development (Hirai, 2018). The activation of PKC induces long-term depression (LTD) and single climbing fiber (CF) innervation to Purkinje cells, which are important for motor coordination (Ito, 2002; Watanabe and Kano, 2011). PKC $\alpha$ knock-down blocks LTD (Leitges et al., 2004), and PKC $\gamma$ deficiency and constitutively active mutant PKC $\gamma$ induce the impairment of cerebellar motor coordination, including the loss of LTD, abnormal dendritic morphology and multiple CF innervation (Chen et al., 1995; Kano et al., 1995;

Received August 10, 2019; accepted January 23, 2020; First published February 7, 2020.

The authors declare no competing financial interests.

Author contributions: R.T., S.U., M.Y., N.S., and Y.S. designed research; R.T., S.Ka., and S.Ki. performed research; Y.F. and M.I. contributed unpublished reagents/analytic tools; R.T. and S.Ka. analyzed data; R.T., S.Ka., Y.F., and Y.S. wrote the paper.

This work was supported by a the JSPS KAKENHI Grant JP16H06276.

Acknowledgements: We thank Yoshitaka Fujihara and Masahito Ikawa for supplying DGK $\gamma$ KO (tm1a) mice and CAG-Flpo transgenic mice.

Correspondence should be addressed to Yasuhito Shirai at shirai@ kobe-u.ac.jp.

https://doi.org/10.1523/ENEURO.0319-19.2020

Copyright (C) 2020 Tsumagari et al.

This is an open-access article distributed under the terms of the Creative Commons Attribution 4.0 International license, which permits unrestricted use, distribution and reproduction in any medium provided that the original work is properly attributed.
Shuvaev et al., 2011). These reports indicate that the regulation of PKC activity is important for cerebellar motor coordination.

Interestingly, a recent study previously reported that DGK $\gamma$ directly interacts with PKC $\gamma$ and is phosphorylated by PKC $\gamma$, resulting in the upregulation of DGK $\gamma$ activity and the subsequent attenuation of PKC activity (Yamaguchi et al., 2006). These facts suggest that DGK $\gamma$ also has important roles in cerebellar motor coordination. However, its physiological role in cerebellar motor coordination has not been elucidated. Therefore, we investigated the function of DGK $\gamma$ in cerebellar motor coordination and its molecular mechanism using DGK $\gamma$ knock-out (KO) mice. We found that DGK $\gamma$ contributes to motor coordination, the induction of cerebellar LTD and the dendritic development of Purkinje cells through the regulation of $\mathrm{PKC} \gamma$.

\section{Materials and Methods}

\section{Materials}

Primers were purchased from Thermo Fisher Scientific. We used the following antibodies: rabbit anti-DGK $\gamma$ (Adachi et al., 2005), rabbit anti-calbindin, rabbit anti-PKC substrate (Cell Signaling), rabbit anti-phospho-PKC $\gamma$ T674 (Bios), rabbit anti-phospho-PKC $\alpha$ S657 (Abcam), rabbit anti-PKC $\gamma$, mouse anti-PKC $\alpha$, mouse anti-GAPDH (Santa Cruz), mouse anti- $\beta$-actin (BD), peroxidase-conjugated AffiniPure goat anti-rabbit and anti-mouse IgG and Alexa Fluor 546 (Alexa 546)-conjugated goat anti-rabbit IgG (Jackson). We used the following cell culture reagents: Sumitomo Nerve-Cell Culture System (Sumitomo Bakelite) and 3,3',5'-triiodo-L-thyronine (T3) sodium salt (Thermo Fisher Scientific). The plasmids, 12-o-tetradecanoylphorbol 13-acetate (TPA), GF109203X (GFX), and Gö6976 (Gö) were donated by Dr. Saito (Biosignal Research Center, Kobe University, Kobe, Japan). Scutellarin (Scu) was purchased from Namiki Shoji.

\section{Mice}

Wild-type (WT) mice (C57BL/6N) were purchased from Japan SLC, Inc. DGK $\gamma$ KO (tm1a) mice and CAG-Flpo transgenic mice were kindly provided by Dr. Ikawa and Dr. Fujihara. Mice were housed under a 14/10 h light/dark cycle with ad libitum food and water. All procedures using mice were performed according to the guidelines of the Institute Animal Care and Use Committee. Male six- to 12-week-old mice were used for the motor coordination tests and the electrophysiological experiments.

\section{Generation of DGK $\gamma$ KO (tm1a) and floxed (tm1c) mice}

A vector targeting the mouse Dgkg gene (PRPGS00045 A_B02) was acquired from the International Knockout Mouse Consortium (IKMC; Skarnes et al., 2011). After linearization by AsiSI digestion, the targeting vector was electroporated into EGR-G101 ((CAG/Acr-Egfp)C57BL/6NCr x (CAG/AcrEgfp)C57BL/6NCr) embryonic stem (ES) cells (Fujihara et al., 2013), and colonies were screened. To disrupt the Dgkg 
gene, exons 4-5 were replaced with an internal ribosomal entry site (IRES): lac $Z$ trapping cassette, a floxed promoter-driven neo cassette, and floxed exons 4-5. A diphtheria-toxin-A-chain (DTA) expression cassette was used for negative selection. After G418 selection, four of the 32 drug-resistant clones underwent a homologous recombination event after $P C R$ analysis. The screening primers were: 5'-CACAACGGGTTCTTCTGTTAGTCC-3' and 5'-GTCATCTAACACAGGAGACCAGTCATG-3' for the 5'-arm; and 5'-ATCCGGGGGTACCGCGTCGAG-3' and 5'-GAAGAGACATGAGAGGCAAGATGC-3' for the 3'-arm. The mutant ES cell clones were injected into eight-cell stage ICR embryos, and the chimeric blastocysts were transferred into the uterine horns of pseudopregnant ICR females the next day. The obtained chimeric males were mated with WT females for germline transmission. Offspring from heterozygous intercrosses were genotyped by PCR.

The DGK $\gamma$ floxed (tm1c) mice, in which the loxP sites flank exons 4-5, were generated by mating DGK $\gamma \mathrm{KO}$ (tm1a) mice with CAG-Flpo transgenic mice using the FLP-flippase recognition target (FRT) recombination system. The transgenic mice express an optimized FLP recombinase (FLPo) under the control of a CAG promoter (Yamazaki et al., 2016). The genotyping primers were: 5'GCAACGTGCTGGTTGTTGTGCTGTCTCATC-3' and 5' TCAGATCCGCCTGTTGATGTAGCTG-3'. The transgenic allele was amplified by PCR, resulting in a 1352-bp band.

\section{Genotyping}

Genotyping of DGK $\gamma$ KO (tm1a) and tm1c mice was conducted by PCR using the following primers: $5^{\prime}$ CAGGTGTCTCTTGTCTGGGCT-3' , 5'-TGGGTATAGGGT AGGAACTTGC-3', and 5'-CACAACGGGTTCTTCTGTTA GTCC-3'. Bands at $907 \mathrm{bp}, 523$ and $975 \mathrm{bp}$ are expected from WT, DGK $\gamma$ KO (tm1a) and tm1c mice, respectively. PCR conditions were as follows, 25- $\mu$ l volume, one cycle at $94^{\circ} \mathrm{C}$ for $2 \mathrm{~min} ; 40$ cycles at $94^{\circ} \mathrm{C}$ for $1 \mathrm{~min}, 62^{\circ} \mathrm{C}$ for $30 \mathrm{~s}$, and $72^{\circ} \mathrm{C}$ for $1 \mathrm{~min}$; one cycle at $72^{\circ} \mathrm{C}$ for $10 \mathrm{~min}$.

\section{Preparation of proteins from the brain}

The cerebellum and cerebrum were obtained from WT, DGK $\gamma$ KO (tm1a), and tm1c mice. These samples were homogenized in ice-cold homogenate buffer [20 mM Tris- $\mathrm{HCl}, 1 \mathrm{mM}$ EGTA, $1 \mathrm{mM}$ EDTA, $1 \mathrm{mM} \mathrm{MgCl} 2,1 \mathrm{mM}$ phenylmethylsulfonyl fluoride (PMSF), $20 \mathrm{ng} / \mathrm{ml}$ leupeptin, $1 \times$ phosphatase inhibitor cocktail solution II (Wako), and 1\% Triton X-100; $\mathrm{pH} 7.4$ ] using a handy sonic sonicator (UR-20, Tomy Seiko Co, Ltd.). After centrifugation, the lysates were obtained.

\section{Western blotting}

Western blotting was performed as described previously (Kano et al., 2014). Briefly, the samples were subjected to $10 \%$ SDS-PAGE, followed by blotting onto a poly-vinylidene difluoride membrane (Millipore). Nonspecific binding sites were blocked by incubation with $5 \%$ skim milk in 0.01 M PBS containing $0.03 \%$ Triton X-100 (PBS-T) for $1 \mathrm{~h}$. The membrane was incubated with the appropriate antibody for $1 \mathrm{~h}$ at room temperature. After washing with PBS-T, the membrane was incubated with peroxidaselabeled anti-rabbit or anti-mouse IgG for $30 \mathrm{~min}$. After three rinses with PBS-T, the immunoreactive bands were visualized using ImmunoStar (Wako). The densities of the bands were analyzed by ImageJ. To detect phosphorylated proteins, we used 5\% BSA instead of skim milk for blocking and $0.01 \mathrm{M}$ TBS containing $0.03 \%$ Tween 20 (TBS-T) instead of PBS-T.

\section{Immunohistochemistry}

For immunohistochemical analysis of mouse brains, mice were perfused with $0.9 \% \mathrm{NaCl}$ through the left ventricle followed by $4 \%$ paraformaldehyde (PFA). The brains were removed and immersed for $48 \mathrm{~h}$ in $4 \%$ PFA at $4^{\circ} \mathrm{C}$. The brains were immersed in a $30 \%$ sucrose solution for at least $2 \mathrm{~d}$ at $4{ }^{\circ} \mathrm{C}$. The brains were sliced with a cryostat (Leica CM1850) to produce 20- $\mu$ m-thick coronal and parasagittal sections. Immunohistochemistry was performed as described previously (Ueda et al., 2013). The sections were incubated in $0.03 \% \mathrm{H}_{2} \mathrm{O}_{2}$ in PBS (-) for $1 \mathrm{~h}$ and permeabilized with $0.3 \%$ Triton $\mathrm{X}-100$ in PBS (-) for $30 \mathrm{~min}$. Subsequently, the sections were washed with $0.1 \%$ Tween 20 in PBS (-) and incubated in $0.1 \%$ Tween 20 in PBS (-) supplemented with goat serum as a blocking reagent for $1 \mathrm{~h}$. Next, the sections were incubated with an appropriate antibody for $72 \mathrm{~h}$ at $4^{\circ} \mathrm{C}$. The bound antibodies were visualized using EnVision + System-HRP (Agilent Technology).

\section{Rotarod test}

The rotarod apparatus (MK-630B single lane rotarod, Muromachi Kikai) consisted of a rod $(30 \mathrm{~mm}$ in diameter, $90 \mathrm{~mm}$ wide) flanked by two large round plates $(40 \mathrm{~cm}$ in diameter). The speed of rotation was increased from four to 40 rotations per minute over $5 \mathrm{~min}$. We recorded the latency for the mice to fall from the rod. The test was performed three times daily for $2 \mathrm{~d}$.

\section{Footprint test}

The hind paws of the mice were coated with nontoxic ink, and the mice were allowed to walk through a tunnel (30 cm long, $16 \mathrm{~cm}$ wide, and $17 \mathrm{~cm}$ high). The footprint patterns were analyzed for stride length. The test was performed three times.

\section{Beam test}

Mice were trained to traverse an elevated metallic beam (70 cm long, $10 \mathrm{~mm}$ in diameter, $60 \mathrm{~cm}$ high). They were placed at one end of the beam and an enclosed escape box was placed at the other end. Each hind paw slip was recorded and counted. The test was performed five times daily for $2 \mathrm{~d}$.

\section{Electrophysiology}

Mice were sacrificed by cervical dislocation under anesthesia with diethyl ether. The cerebellum was excised, and parasagittal cerebellar slices $(250 \mu \mathrm{m}$ thick) were 
prepared from the vermis (Edwards et al., 1989; Kakizawa et al., 2000, 2012). Whole-cell recordings were obtained from visually identified Purkinje cells under an upright microscope (BX51WI, Olympus) using a 40× water-immersion objective at room temperature $\left(23-25^{\circ} \mathrm{C}\right)$. The resistance of the patch pipettes was 2.0-3.5 $\mathrm{M} \Omega$ when filled with an intracellular solution composed of the following: $130 \mathrm{mM}$ K-gluconate, $10 \mathrm{mM} \mathrm{KCl}, 10 \mathrm{mM} \mathrm{NaCl}, 1 \mathrm{mM}$ EGTA, $4 \mathrm{mM}$ ATP-Mg, $0.4 \mathrm{mM}$ GTP-Na, and $10 \mathrm{mM}$ HEPES ( $\mathrm{pH} 7.3$; adjusted with $\mathrm{KOH}$ ). The standard bathing solution was composed of the following: $125 \mathrm{mM}$ $\mathrm{NaCl}, 2.5 \mathrm{mM} \mathrm{KCl}, 2 \mathrm{mM} \mathrm{CaCl}_{2}, 1 \mathrm{mM} \mathrm{MgSO}_{4}, 1.25 \mathrm{mM}$ $\mathrm{NaH}_{2} \mathrm{PO}_{4}, 26 \mathrm{mM} \mathrm{NaHCO}_{3}$, and $20 \mathrm{mM}$ glucose, bubbled with $95 \% \mathrm{O}_{2}$ and $5 \% \mathrm{CO}_{2}$. Bicuculline $(10 \mu \mathrm{M})$ was always added to block the IPSCs. Scu $(100 \mu \mathrm{m})$ was added to the extracellular solution for $1 \mathrm{~h}$ prior to the stimulation. For focal stimulation of parallel fibers (PFs), a stimulation pipette (with a tip 5-10 $\mu \mathrm{m}$ in diameter) was filled with standard bathing solution and used to apply square pulses (0.1 $\mathrm{ms}$ in duration, $0-20 \mathrm{~V}$ in amplitude) to the middle portion of the molecular layer. The intensity of each stimulus was adjusted to evoke PF-excitatory postsynaptic currents (EPSCs) with amplitudes of $60-120 \mathrm{pA}$. The ionic current was recorded from Purkinje cells using a patchclamp amplifier (EPC-9, HEKA) at a holding potential of -90 or $-80 \mathrm{mV}$, after compensating for liquid junction potential. The signals were filtered at $2 \mathrm{kHz}$ and digitized at $20 \mathrm{kHz}$.

On-line data acquisition and off-line data analyses were performed using PULSE (HEKA) software. For the LTD experiments, the intensity of the stimulus was adjusted to evoke PF-EPSCs whose initial amplitudes were between 60 and $120 \mathrm{pA}$. After obtaining a stable initial recording for at least $10 \mathrm{~min}$, conjunctive stimulus (CJS) was applied to induce LTD. The CJS protocol is composed of 300 single PF stimuli in conjunction with depolarizing pulse ( -80 to $0 \mathrm{mV}$ for $50 \mathrm{~ms}$ ) in conjunction with single PF stimuli (at $40 \mathrm{~ms}$ after the onset of the pulse) at $1 \mathrm{~Hz}$. The test stimulus was applied to PFs every $10 \mathrm{~s}$. The amplitude of PF-EPSCs was averaged every $60 \mathrm{~s}$, and normalized to the mean value observed $10 \mathrm{~min}$ before the LTD-inducing stimulus. A $100 \mathrm{~ms},-5 \mathrm{mV}$ hyperpolarizing test pulse preceded each PF stimulus to monitor the series resistance and input resistance of Purkinje cells throughout the experiment. Data were discarded if the resistance changed by $>10 \%$ (Kakizawa et al., 2012). Data were also discarded when the slope of PF-EPSC amplitude averaged every minute during the initial recording for $10 \mathrm{~min}$ was larger than $2 \%$ or when the amplitude did not become stable within $20 \mathrm{~min}$ after the onset of whole-cell configuration.

For the analysis of membrane capacitance of Purkinje cells, hyperpolarizing current pulse $(-80$ to $-90 \mathrm{mV}$, for $500 \mathrm{~ms}$ ) was applied, and the resulting capacitive current was recorded. Membrane capacitances were then calculated according to the model described previously (Llano et al., 1991), which distinguishes two regions of Purkinje cells: region 1 representing the soma and the main proximal dendrites, and region 2 representing the dendritic tree. $\mathrm{C} 1$ represents the membrane capacitance of region
1, and C2 represent the capacitance of the dendritic tree of Purkinje cells.

To examine number of CFs innervating the recorded Purkinje cell, we systematically moved the stimulation pipette in the granule cell layer and tried stimulation at 10 different sites. The stimulus intensity was gradually increased at each stimulation site. When a CF was stimulated, an EPSC was elicited in an all-or-none fashion. In some Purkinje cells, more than one discrete CF-EPSC could be elicited when the stimulus intensity was increased or when the stimulating electrode was moved to a different site. The number of CFs innervating the Purkinje cell was estimated by counting the number of discrete CF-EPSC steps elicited in that cell (Kano et al., 1995; Kakizawa et al., 2000, 2003).

\section{Primary culture of mouse Purkinje cells}

Dissociated cerebellar cultures were prepared as described previously (Seki et al., 2009). EXVIII embryos were removed from pregnant WT and DGK $\gamma$ KO mice anesthetized with Ravonal. The cerebellum was dissected and kept in ice-cold HBSS (Wako). Cerebellar cells were dissociated by using dissociation solutions from the Sumitomo Nerve-Cell Culture System according to the manufacturer's instructions. Dissociated cerebellar cells were suspended in neuronal culture medium from the Sumitomo Nerve-Cell Culture System, and plated at a concentration of $1 \times 10^{5}$ cells $/ 50 \mu$ in the center of a multi-well glass bottom dish (Matsunami Glass) coated with polyethylenimine (Sigma-Aldrich), and cultured in a humidified atmosphere containing $5 \% \mathrm{CO}_{2}$ at $37^{\circ} \mathrm{C}$. After the cells attached to the bottom (1-2 h later), $250 \mu$ l of culture medium was added to each well. The culture medium was supplemented with 100 рм T3. The cells were cultured for $21 \mathrm{~d}$ in vitro (DIV). Half of the medium was changed every 3-4 d. TPA (200 nм), GFX (200 nм), and Gö (1 $\mu \mathrm{M})$ were added to the medium for $3 \mathrm{~d}$.

\section{Confocal microscopy}

For immunofluorescent staining, primary cultured Purkinje cells at DIV21 were fixed with $4 \%$ PFA for $1 \mathrm{~h}$ at $4^{\circ} \mathrm{C}$. After fixation, the cells were permeabilized with $0.3 \%$ Triton X100 for $30 \mathrm{~min}$ and then blocked with 10\% normal goat serum (NGS) for $2 \mathrm{~h}$. The cells were incubated with anti-calbindin antibody for $16 \mathrm{~h}$ at $4^{\circ} \mathrm{C}$ and then visualized with Alexa 546-labeled goat anti-rabbit IgG, followed by observation under confocal microscopy.

The fluorescence of Alexa 546 was observed with a confocal laser scanning fluorescence microscope (FV500 IX81 Olympus). The images were recorded as TIFF files. To count the number of neurites and branches and their lengths, the images were analyzed with Neurolucida and Neurolucida Explorer software (MBF Bioscience).

\section{Measurement of PA in the crude synaptosomal membrane fraction}

Crude synaptosomes were prepared as described previously (Gu et al., 2009). Briefly, the cerebellum was homogenized in sucrose buffer: $320 \mathrm{mM}$ sucrose, $20 \mathrm{mM}$ 
Tris- $\mathrm{HCl}, 1 \mathrm{mM}$ EGTA, $1 \mathrm{mM}$ EDTA, $1 \mathrm{mM} \mathrm{MgCl}, 1 \mathrm{mM}$ PMSF, $20 \mathrm{ng} / \mathrm{ml}$ leupeptin, $1 \mathrm{mM} \mathrm{NaF}, 1 \mathrm{mM} \mathrm{Na}_{3} \mathrm{VO}_{4}$ and $1 \times$ phosphatase inhibitor cocktail solution II; $\mathrm{pH}$ 7.4) with a Potter-Elvehjem homogenizer. After centrifugation at $800 \times g$ for $5 \mathrm{~min}$, the supernatant was centrifuged at $10,000 \times g$ for $10 \mathrm{~min}$. The pellet (crude synaptosome fraction) was homogenized in sucrose buffer containing $1 \%$ Triton X-100 and $300 \mathrm{~mm} \mathrm{NaCl}$ and centrifuged at $16,000 \times g$ for $30 \mathrm{~min}$. The supernatant (S2) and pellet (P2) were obtained, and the P2 fraction was dissolved in $1 \%$ SDS.

PA was measured as described previously (Morita et al., 2009). Equal amounts of crude synaptosomal membrane fraction (P2) and $1 \mathrm{M} \mathrm{NaCl}$ were mixed, and $20 \mu \mathrm{l}$ of $1 \%$ perchloric acid (PCA), $450 \mu$ l of chloroform/methanol (1 : 2), $150 \mu \mathrm{l}$ of chloroform and $150 \mu \mathrm{l}$ of $1 \%$ PCA were added to the samples in order. After centrifugation at $10,000 \mathrm{rpm}$ for $2 \mathrm{~min}$, the lower layer was harvested and dried. The extracts were dissolved in $70 \mu \mathrm{l}$ of $1 \%$ Triton $\mathrm{X}-100$. Then, $30 \mu \mathrm{l}$ of the solution and $120 \mu \mathrm{l}$ of reagent buffer A1 $(50 \mathrm{mM}$ Tris- $\mathrm{HCl}, 50 \mathrm{mM} \mathrm{NaCl}$, and $10 \mathrm{kU} / \mathrm{ml}$ $\mathrm{LPL} ; \mathrm{pH}$ 7.4) were mixed and reacted for $1 \mathrm{~h}$ at $37^{\circ} \mathrm{C}$. After incubation for $3 \mathrm{~min}$ at $96^{\circ} \mathrm{C}$, the mixture was centrifuged at $10,000 \mathrm{rpm}$ for $5 \mathrm{~min}$ at room temperature. A total of $50 \mu \mathrm{l}$ of the supernatant and $50 \mu \mathrm{l}$ of reagent buffer A2 (50 $\mathrm{mM}$ Tris- $\mathrm{HCl}, 50 \mathrm{mM} \mathrm{NaCl}, 0.2 \%$ Triton X-100, $5 \mathrm{U} / \mathrm{ml}$ HRP, and $0.3 \mathrm{mM}$ Amplex Red) were mixed and reacted for $30 \mathrm{~min}$ at room temperature. Then, the amount of PA was measured using a Wallac 1420 ARVOsx (PerkinElmer).

\section{Evaluation of the inhibitory effect of scutellarin on PKC $\gamma$ and PKC $\alpha$ activities}

COS-7 cells were cultured in DMEM supplemented with $10 \%$ FBS, penicillin (100 units $/ \mathrm{ml}$ ) and streptomycin $(100 \mu \mathrm{g} / \mathrm{ml})$. The cells were cultured at $37^{\circ} \mathrm{C}$ in a humidified atmosphere containing $5 \% \mathrm{CO}_{2}$. A plasmid (PKC $\gamma$ GFP or PKC $\alpha$-GFP) was electroporated into COS-7 cells using a gene pulser (Bio-Rad). After being cultured for $2 \mathrm{~d}$, the cells were preincubated with scutellarin (Scu) for $30 \mathrm{~min}$ and then treated with $100 \mathrm{~nm}$ TPA for $30 \mathrm{~min}$ in Ringer's solution ( $5 \mathrm{mM}$ HEPES, $165 \mathrm{mM} \mathrm{NaCl}, 5 \mathrm{mM} \mathrm{KCl}$, $1 \mathrm{mM} \mathrm{CaCl}_{2}, 1 \mathrm{mM} \mathrm{MgCl}_{2}$, and $10 \mathrm{mM}$ glucose; $\mathrm{pH}$ 7.4). After that, the cells were harvested and homogenized in lysis buffer (20 mM Tris-HCl, 1 mM EGTA, 1 mM EDTA, 1 $\mathrm{mM} \mathrm{MgCl}$, $1 \mathrm{mM}$ PMSF, $20 \mathrm{ng} / \mathrm{ml}$ leupeptin, $5 \mathrm{mM} \mathrm{NaF}$, 2 $\mathrm{mM} \mathrm{Na} \mathrm{VO}_{4} 1 \mathrm{mM} \mathrm{C} \mathrm{C}_{4} \mathrm{H}_{4} \mathrm{Na}_{2} \mathrm{O}_{6} \cdot 2 \mathrm{H}_{2} \mathrm{O}$, and $1 \mathrm{mM}$ $\mathrm{C}_{3} \mathrm{H}_{7} \mathrm{Na}_{2} \mathrm{O}_{6} \mathrm{P} \cdot \mathrm{nH}_{2} \mathrm{O} ; \mathrm{pH}$ 7.4) using a handy sonic sonicator. After centrifugation, the lysates were subjected to Western blotting using anti-phospho-PKC $\gamma$ (T674), anti-phosphoPKC $\alpha$ (S657), anti-PKC $\gamma$, and anti-PKC $\alpha$ antibodies.

Parasagittal cerebellar slices $(300 \mu \mathrm{m}$ thick) were prepared from the vermis (Edwards et al., 1989; Kakizawa et al., 2000, 2012). The slices were incubated in standard artificial CSF (ACSF; $125 \mathrm{mM} \mathrm{NaCl}, 2.5 \mathrm{mM} \mathrm{KCl}, 2 \mathrm{mM} \mathrm{CaCl}_{2}$, $1.3 \mathrm{mM} \mathrm{MgCl}_{2}, 1.25 \mathrm{mM} \mathrm{NaH}_{2} \mathrm{PO}_{4}, 26 \mathrm{mM} \mathrm{NaHCO}_{3}$, and $20 \mathrm{mM}$ glucose) for $30 \mathrm{~min}$ at $37^{\circ} \mathrm{C}$ and then incubated for $1 \mathrm{~h}$ at room temperature in standard ACSF with or without Scu. The slices were subsequently homogenized in lysis buffer (50 mM Tris-HCl, $150 \mathrm{mM} \mathrm{NaCl}, 1 \mathrm{mM}$ EDTA, $1 \mathrm{mM}$ PMSF, 20 ng/ml leupeptin, 100 mM NaF, $2 \mathrm{mM} \mathrm{Na}_{3} \mathrm{VO}_{4}, 20$
$\mathrm{mM} \mathrm{Na}{ }_{4} \mathrm{P}_{2} \mathrm{O}_{7}, 1 \%$ Triton $\mathrm{X}-100$, and $10 \%$ glycerol; $\mathrm{pH} 7.5$ ) using a handy sonic sonicator. After centrifugation, the lysates were subjected to Western blotting using anti-phospho-PKC $\gamma$ (T674), anti-phospho-PKC $\alpha$ (S657), anti-PKC $\gamma$, and anti-PKC $\alpha$ antibodies.

\section{Experimental design and statistical analysis}

All animal data were analyzed for male mice. All data are shown as the mean \pm SEM, and Student's $t$ test, Dunnett's test, and Tukey's multiple comparisons test were used as appropriate to test statistical significance. Data were analyzed using Excel (Microsoft) and $\mathrm{R}$ version 3.5.1 (The $\mathrm{R}$ Foundation for Statistical Computing). The statistical analysis of multiple CFs was performed using the Kolmogorov-Smirnov test (Igor Pro, Hulkins). Differences were considered significant when $p<0.05$.

\section{Results}

\section{Generation of DGK $\gamma$ KO mice}

We produced homozygous tm1a mice (tm1a/tm1a) by mating tm1a heterozygous mice containing a promotordriven cassette (Fig. 1A). The genotype of the tm1a/tm1a mice was confirmed by PCR (Fig. 1C). However, we could not confirm that DGK $\gamma$ was not expressed in the brains of $\mathrm{tm} 1 \mathrm{a} / \mathrm{tm} 1 \mathrm{a}$ mice, because the insertion occurred between exons 3 and four of the gene that encodes DGK $\gamma$. Therefore, we examined DGK $\gamma$ expression in the brain by Western blotting and immunohistochemistry using an anti-DGK $\gamma$ antibody. Western blotting revealed that there was no expression of DGK $\gamma$ in the cerebrum or cerebellum of tm1a/tm1a mice (Fig. 1C). DGK $\gamma$ immunoreactivity was clearly observed in the hippocampus and cerebellar Purkinje cells and weakly and diffusely expressed in the granule cells of WT mice, but not in those of $t \mathrm{tm} 1 \mathrm{a} / \mathrm{tm} 1 \mathrm{a}$ mice (Fig. $1 D, E$ ). These results indicate that the DGK $\gamma$ protein was not expressed in the brains of $t \mathrm{tm} 1 \mathrm{a} / \mathrm{tm} 1 \mathrm{a}$ mice; thus, we concluded that these mice were DGK $\gamma$ KO mice.

\section{Motor coordination of DGK $\gamma$ KO mice}

DGK $\gamma$ is abundantly expressed in cerebellar Purkinje cells which are important for motor coordination (Goto and Kondo, 1999; Adachi et al., 2005). Thus, we tested the motor coordination of DGK $\gamma \mathrm{KO}$ mice by the rotarod, footprint and beam tests. In the rotarod test, WT and DGK $\gamma$ KO mice showed steady improvements over trials, but the latency for DGK $\gamma$ KO mice to fall from the rod was significantly shorter than that of WT mice (Fig. 2A; ${ }^{*} p<0.05,{ }^{* *} p<0.01$; Student's $t$ test). In the footprint test, WT and DGK $\gamma$ KO mice seemed to walk normally (Fig. 2B). However, a precise analysis of the hind footprint pattern revealed that the stride length of DGK $\gamma \mathrm{KO}$ mice was significantly $(\sim 15 \%)$ shorter than that of WT mice (Fig. 2C; $p=0.023$; Student's $t$ test). In the beam test, DGK $\gamma$ KO mice exhibited significantly more frequent slips than WT mice (Fig. 2D; $p=0.033$, Student's $t$ test). These results clearly indicate that DGK $\gamma \mathrm{KO}$ mice show impairments in motor coordination. 


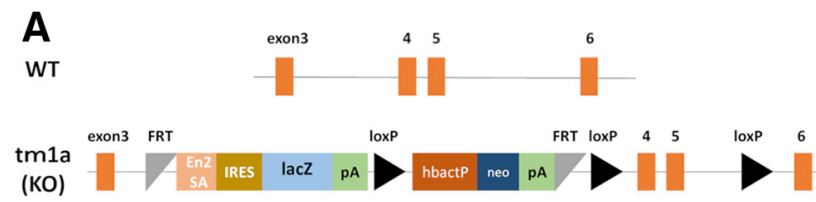

B

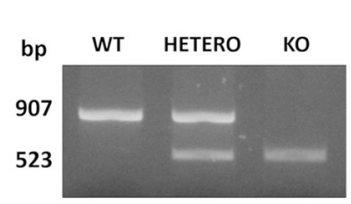

C
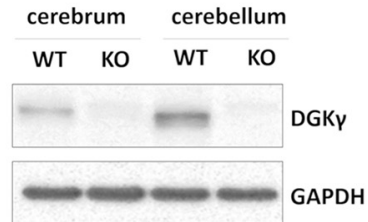

D

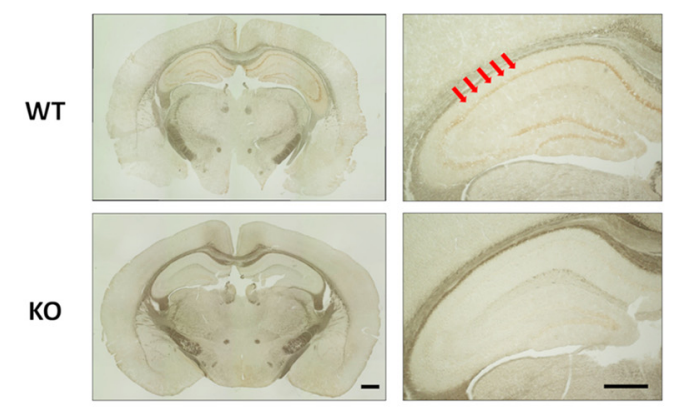

E

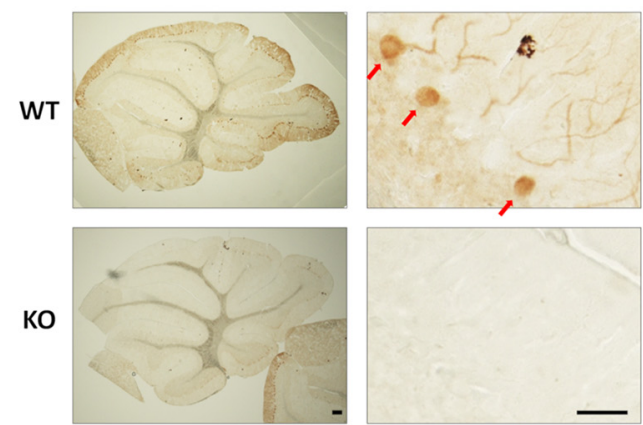

Figure 1. Generation of DGK $\gamma \mathrm{KO}$ mice and PCR genotyping. $\boldsymbol{A}$, Promotor-driven cassette inserted between exons 3 and 4 of the gene that encodes DGK $\gamma$. En2SA, engrailed 2 splice acceptor; lacZ, $\beta$-galactosidase; $\mathrm{pA}$, adenovirus polyadenylation signal; loxP, Cre recombinase recognition sequence; hbactP, human- $\beta$-actin promotor; neo, neomycin. $\boldsymbol{B}$, Typical result of PCR genotyping. Bands at 907 and 523 bp were expected for the WT and tm1a alleles, respectively. $\boldsymbol{C}$, Cerebral and cerebellar lysates from WT and DGK $\gamma$ KO mice were subjected to Western blotting and probed with an anti-DGK $\gamma$ antibody. $\boldsymbol{D}, \boldsymbol{E}$, Coronal sections of the cerebrum $(\boldsymbol{D})$ and parasagittal sections of the cerebellum $(\boldsymbol{E})$ were subjected to immunohistochemistry and stained with an anti-DGK $\gamma$ antibody. The red arrows show the hippocampus and Purkinje cells. Scale bars: $500 \mu \mathrm{m}(\boldsymbol{D}$, right and left, $\boldsymbol{E}$, left) and $100 \mu \mathrm{m}$ (E, right).

\section{LTD in DGK $\gamma$ KO mice}

Since cerebellar LTD is a basis of motor coordination, we examined cerebellar LTD in DGK $\gamma$ KO mice. LTD was induced by CJS, which is paired depolarization and parallel fiber (PF) stimulation at $1 \mathrm{~Hz}$ for $300 \mathrm{~s}$ (Kakizawa et al., 2012), and the amplitude of EPSCs at PF-to-Purkinje cell synapses (PF synapses) after CJS was decreased in WT mice. In contrast, DGK $\gamma$ KO mice showed impaired LTD (Fig. $3 A, B ; p=0.0003$, Student's $t$ test); the average EPSC amplitude of DGK $\gamma$ KO mice 21-30 min after CJS were equal to baseline levels. On the other hand, no significant abnormalities were observed in the electrophysiological properties of PF synapses; there was no significant difference in the input-output relationship, that is, the slope of the EPSC amplitude (output)-stimulus intensity (input) curve, between WT and DGK $\gamma$ KO mice (Fig. 3C; $p>$ 0.05 , Student's $t$ test). Additionally no significant difference was observed in the paired-pulse ratio (PPR; Fig. $3 D ; p>0.05$, Student's $t$ test), an index of the change in transmitter release probability at presynaptic terminals (Zucker and Regehr, 2002). Taken together, the data indicate that, although the basic electrophysiological properties of PF synapses were normal, cerebellar LTD was impaired in DGK $\gamma \mathrm{KO}$ mice.

\section{CF innervation to Purkinje cells in DGK $\gamma$ KO mice}

CF innervation of Purkinje cells is also responsible for motor coordination. Single Purkinje cells are originally innervated by multiple CFs; however, they are innervated by a single CF as they grow due to pruning (Watanabe and Kano, 2011). A deficiency in the mGluR1-PKC $\gamma$ signaling cascade results in multiple CF innervation in mature Purkinje cells and subsequent impaired motor coordination (Kano et al., 1995, 1997, 1998; Offermanns et al., 1997). Therefore, we investigated the number of CFs innervating Purkinje cells in DGK $\gamma$ KO mice. Multiple $\mathrm{CF}$ innervation was not observed in DGK $\gamma \mathrm{KO}$ mice (Fig. $3 E ; p=0.473$, Kolmogorov-Smirnov test). These results indicate that DGK $\gamma$ deficiency did not affect CF innervation in Purkinje cells.

\section{Dendritic development of Purkinje cells in DGK $\gamma$ KO mice}

Next, we investigated the dendritic morphology of Purkinje cells in DGK $\gamma$ KO mice, because the dendritic morphology of Purkinje cells is also important for motor coordination. Purkinje cells were visualized by filling them with fluorescent dye from the a recording pipette, and impairments in the dendritic development of Purkinje cells were revealed in DGK $\gamma$ KO mice (Fig. $4 A$ ); the number of branches and the total length of the dendrites in DGK $\gamma$ $\mathrm{KO}$ mice were significantly lower than those in WT mice, although there was no significant difference in the number of dendrites per cell (Fig. 4B). Sholl analysis demonstrated that there were fewer branches in distal dendrites at distances of 120,140 , and $150 \mu \mathrm{m}$ from the soma in KO mice (Fig. $4 C ; 120 \mu \mathrm{m}: p=0.045,140 \mu \mathrm{m}: p=0.043,150 \mu \mathrm{m}$ : $p=0.006$, Student's $t$ test).

In some cases, a smaller dendritic region is reflected by decreased membrane capacitance (Kakizawa et al., 2003). Therefore, we subsequently examined the membrane capacitance of Purkinje cells. Although there was no significant difference in the membrane capacitance of the somata and proximal dendrites, the membrane capacitance of the distal dendritic region was significantly lower in DGK $\gamma$ KO mice than in WT mice (Fig. 4D; soma + prox. dend.: $p=0.305$, distal dendrite: $p=0.009$, Student's $t$ test). This result is consistent with the impaired morphology of Purkinje cells in DGK $\gamma \mathrm{KO}$ mice. 


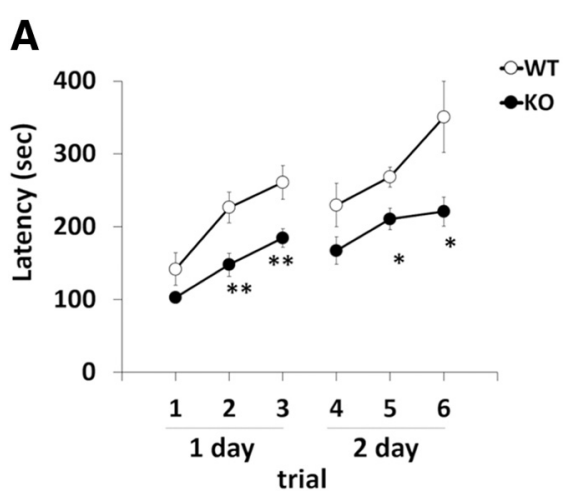

C

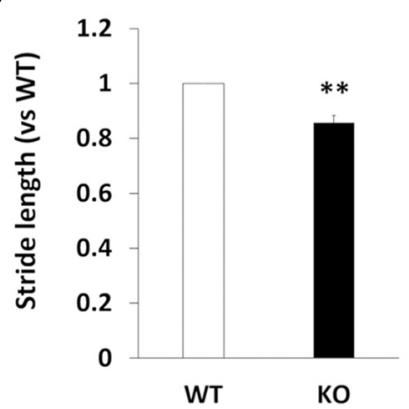

B



D

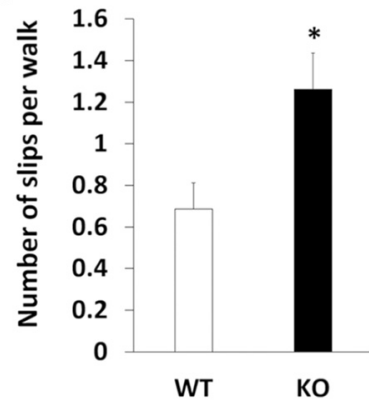

Figure 2. Analysis of motor coordination. A, Motor coordination of WT and DGK $\gamma$ KO mice was assessed by the accelerating rotarod test. The test was performed three times daily for $2 \mathrm{~d}$ (WT: $n=9$; KO: $n=9$ ); $* p<0.05, * * p<0.01$, followed by Student's $t$ test. $\boldsymbol{B}, \boldsymbol{C}$, WT and DGK $\gamma$ KO mice were allowed to walk through a tunnel, and their footprints were recorded on paper. The ratio of the stride length of DGK $\gamma \mathrm{KO}$ mice to the stride length of WT mice was analyzed (WT: $n=5 ; \mathrm{KO}: n=5$ ); **p $<0.01$, followed by Student's $t$ test. $\boldsymbol{D}$, Motor coordination of WT and DGK $\gamma$ KO mice was assessed by the number of hind paw slips in the beam test. The test was performed five times daily for $2 \mathrm{~d}$ (WT: $n=7 ; \mathrm{KO}: n=8$ ); $* p<0.05$, followed by Student's $t$ test. Data are expressed as mean \pm SEM.

To confirm dendritic morphologic impairments in Purkinje cells from DGK $\gamma$ KO mice, we compared morphologic differences between primary cultured Purkinje cells from WT and DGK $\gamma$ KO mice. Primary cultured Purkinje cells prepared from EXVIII embryos were cultured for 21 DIV and stained with an anti-calbindin antibody (Fig. 5A). The number of branches and total length of dendrites of primary cultured Purkinje cells from DGK $\gamma$ KO mice were significantly decreased compared with those from WT mice (control (con) in Fig. 5B, center and right; WT con vs KO con, branches: $p=0.000013$, length: $p=0.000056$, Tukey's multiple comparison test). However, there was no difference in the number of dendrites per cell (con in Fig. $5 B$, left; $p>0.05$, Tukey's multiple comparison test). These results confirm the impaired branching of Purkinje cells from DGK $\gamma$ KO mice.

To investigate the molecular mechanism underlying the morphologic impairment of primary cultured Purkinje cells from DGK $\gamma$ KO mice, we focused on PKC activity because PKC is involved in the dendritic morphology of Purkinje cells and its activation results in the retraction of dendrites and a reduction in the number of branches (Metzger and Kapfhammer, 2000); an increase in DG due to DGK $\gamma$ deficiency activates PKC in primary cultured Purkinje cells from DGK $\gamma$ KO mice. Therefore, we treated primary cultured Purkinje cells with a PKC activator TPA and the
panPKC inhibitor GF109203X (GFX) for the final $3 \mathrm{~d}$. These pharmacological treatments did not change the number of dendrites in Purkinje cells from either WT or DGK $\gamma$ KO mice (Fig. 5B, left; $p>0.05$, Tukey's multiple comparison test). In contrast, TPA treatment reduced the number of branches and total length of dendrites of Purkinje cells from WT mice but not of Purkinje cells from DGK $\gamma$ KO mice (TPA in Fig. $5 B$, center and right; WT con vs WT TPA, branches: $p=0.0026$, length: $p=0.0013 ; \mathrm{KO}$ con vs KO TPA, branches: $p=1.00$; length: $p=0.98$, Tukey's multiple comparison test). On the other hand, the decreased number of branches and total length of dendrites of Purkinje cells from DGK $\gamma$ KO mice were rescued to WT levels by treatment by the PKC inhibitor GFX (GFX in Fig. 5B, center and right; KO con vs KO GFX, branches: $p=0.00,041$, length: $p=0.0066$, Tukey's multiple comparison test). These results indicate that PKC activation is key for the morphologic impairment of primary cultured Purkinje cells from KO mice. To further investigate the PKC subtypes involved in these phenomena, we used the CPKC inhibitor Gö6976. Similar to GFX treatment, Gö treatment rescued the impairments in Purkinje cells from DGK $\gamma$ KO mice (Gö in Fig. $5 B$, center and right; KO con vs KO Gö, branches: $p=0.042$, length: $p=0.043$, Tukey's multiple comparison test). These results suggest that DGK $\gamma$ contributes to the dendritic development of Purkinje cells via the regulation of cPKC activity. 

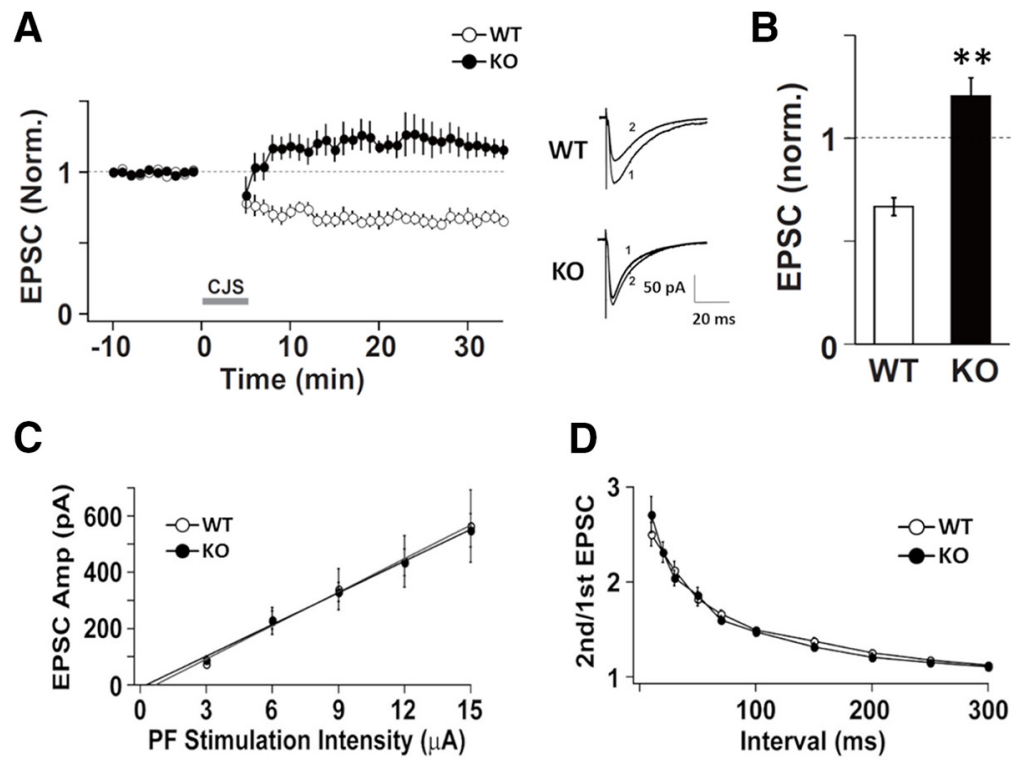

D
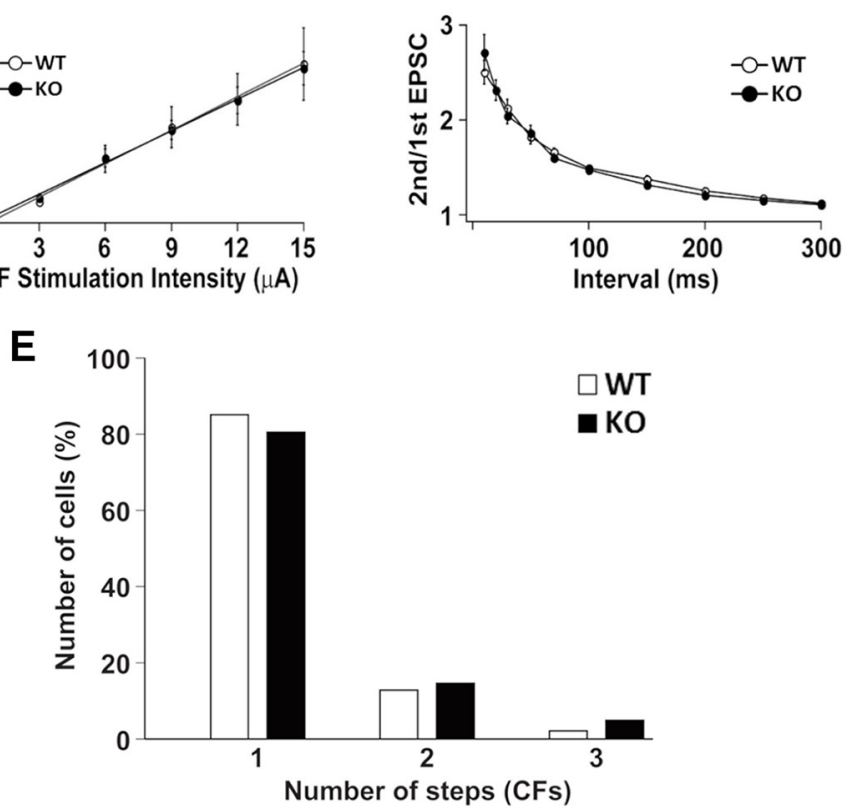

Figure 3. Electrophysiological properties of Purkinje cells in DGK $\gamma$ KO mice. $\boldsymbol{A}$, Changes in the PF-EPSC amplitude before and after the CJS of PFs $(1 \mathrm{~Hz}, 300 \mathrm{~s})$ with depolarization applied at time 0 . The PF-EPSC amplitude was normalized to the mean over 10 min before CJS (WT: $n=5$; KO: $n=5$ ). Sample traces immediately before (1) and 30 min after (2) CJS. B, Average PF-EPSC amplitude over the 21- to 30-min period after CJS; $* * p<0.01$, followed by Student's $t$ test. $\mathbf{C}$, The input-output relationship of PFEPSCs. The PF-EPSCs amplitudes of Purkinje cells from WT and DGK $\gamma$ KO mice plotted as a function of stimulus intensity (WT: $n=11$; KO: $n=10)$. $\boldsymbol{D}$, The PPR of PF-EPSCs recorded from Purkinje cells from WT or DGK $\gamma$ KO mice at several interpulse intervals (WT: $n=11$; KO: $n=10$ ). $E$, Summary histograms showing the percentage of discrete steps of CF-EPSCs (WT: $n=47$; KO: $n=41$ ). Data are expressed as mean \pm SEM.

\section{PKC $\gamma$ activation in the cerebellum of DGK $\gamma$ KO mice}

Among cPKCs, PKC $\alpha$ and $\mathrm{PKC} \gamma$ are expressed in Purkinje cells and they regulate LTD and the dendritic development of Purkinje cells. To confirm whether the activation of PKC indeed occurs in the cerebellum of DGK $\gamma$ $\mathrm{KO}$ mice in vivo, we investigated the autophosphorylation levels of PKC $\alpha$ and PKC $\gamma$ as hallmarks of PKC activity. The phosphorylation of PKC $\gamma$ in the cerebellum of DGK $\gamma$ $\mathrm{KO}$ mice was upregulated, while that of PKC $\alpha$ was not changed (Fig. $6 A ;$ PKC $\gamma: p=0.034$ PKC $\alpha: p=0.69$, Student's $t$ test), indicating that $\mathrm{PKC} \gamma$ was activated in the cerebellum of DGK $\gamma$ KO mice. The loss of DGK $\gamma$ did not affect the expression levels of PKC $\alpha$ or PKC $\gamma$ (Fig. $6 B$; PKC $\gamma: p=0.28$; PKC $\alpha: p=0.95$, Student's $t$ test). Furthermore, we investigated whether PKC is actually activated in the cerebellum of DGK $\gamma \mathrm{KO}$ mice by Western blotting using an anti-PKC substrate antibody that recognizes PKC phosphorylation sites (Fig. 6C). Quantification of the band intensity revealed that the phosphorylation of total PKC substrates was elevated in the cerebellum of DGK $\gamma$ KO mice (Fig. $6 C ; p=0.021$, Student's $t$ test), indicating that PKC was indeed activated in DGK $\gamma$ KO mice.

The upregulation of PKC activity is results from an increase in the DG level induced by DGK $\gamma$ deficiency. In other words, the PA level is reduced in DGK $\gamma \mathrm{KO}$ mice. Therefore, we measured the level of PA in the P2 (crude synaptosomal membrane) fraction of DGK $\gamma \mathrm{KO}$ mice. The level of PA in the P2 fraction of DGK $\gamma$ KO mice was significantly decreased compared with that of WT mice (Fig. $6 D ; p=0.033$, Student's $t$ test). These results suggest that activated PKC $\gamma$ causes abnormalities in the dendritic development of Purkinje cells and LTD, resulting in the impairment of motor coordination. 
A



KO

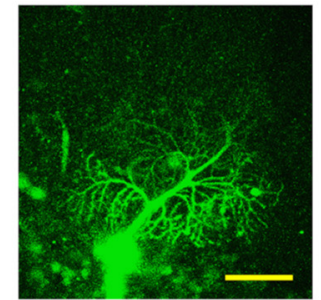

B

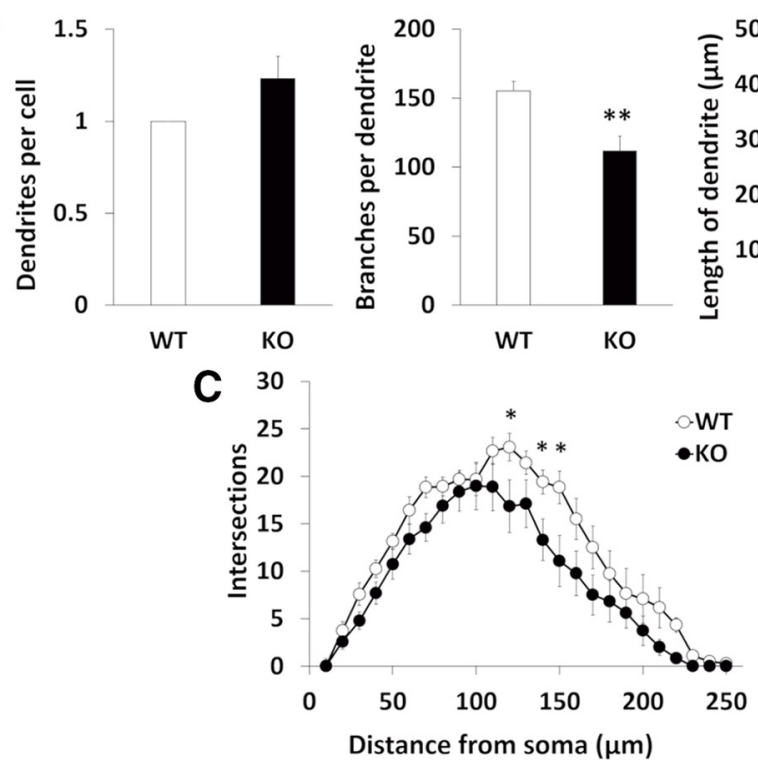

D Tั Soma + Prox. Dend.

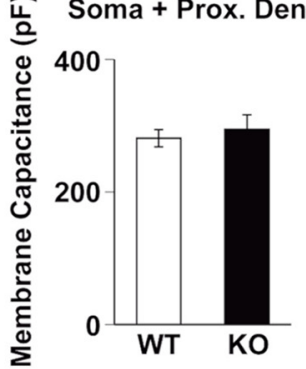

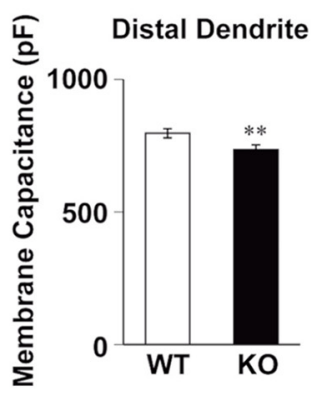

Figure 4. Morphology of Purkinje cells in the cerebellum of DGK $\gamma$ KO mice. $\boldsymbol{A}$, Images of Purkinje cells in cerebellar slices from WT and DGK $\gamma$ KO mice. Purkinje cells were filled with fluorescent dye from the patch pipette. Scale bar: $50 \mu \mathrm{m}$. $\boldsymbol{B}, \mathrm{A}$ comparison of the number of dendrites and branches and the total length of Purkinje cells from WT and DGK $\gamma$ KO mice (WT: $n=12 ; \mathrm{KO}: n=13$ ); $* p<0.05, * * p<0.01$, followed by Student's $t$ test. $\boldsymbol{C}$, Sholl analysis of the number of intersections of Purkinje cells from WT and DGK $\gamma$ KO mice (WT: $n=12$; KO: $n=13$ ); $* p<0.05$, followed by Student's $t$ test. $\boldsymbol{D}$, Membrane capacitance of the somatic and proximal dendritic regions (soma + prox. dend.) and the distal dendritic region (distal dendrite) of cerebellar Purkinje cells (WT: $n=24$; KO: $n=21$ ); $* p<0.05$, followed by Student's $t$ test. Data are expressed as mean \pm SEM.

\section{Effect of a PKC $\gamma$ inhibitor on impaired LTD in DGK $\gamma$ KO mice}

It is known that PKC $\alpha$ but not PKC $\gamma$ is important for LTD. However, we found that there was no change in the activation of PKC $\alpha$ and that PKC $\gamma$ was activated in the cerebellum of DGK $\gamma$ KO mice in the basal state. To investigate the involvement of abnormal PKC $\gamma$ activation in impaired LTD in DGK $\gamma$ KO mice, we used a PKC $\gamma$ inhibitor. Scutellarin (Scu) is a flavonoid that is a major active ingredient of Erigeron breviscapus Hand. Mazz., a plant used in Chinese herbal medicine. A recent study reported that Scu inhibits the translocation of PKC $\gamma$ from the cytoplasm to the plasma membrane which is a hallmark of PKC activation, but has no effect on the translocation of PKC $\alpha$ (Xu et al., 2007; Su et al., 2012), suggesting that Scu specifically inhibits PKC $\gamma$ activity but not $\mathrm{PKC} \alpha$ activity. Therefore, we tried to confirm its inhibitory effect on the autophosphorylation of $\operatorname{PKC} \gamma$ and $\operatorname{PKC} \alpha$. Stimulating COS-7 cells overexpressing PKC $\gamma$-GFP or PKC $\alpha$-GFP with TPA induced the autophosphorylation of both PKC $\gamma$ and PKC $\alpha$ (Fig. 7A; PKC $\gamma: p=0.047$ PKC $\alpha$ : $p=0.0021$, Dunnett's test). However, pretreating the cells with Scu significantly inhibited the autophosphorylation of PKC $\gamma$ but not the autophosphorylation of PKC $\alpha$ 


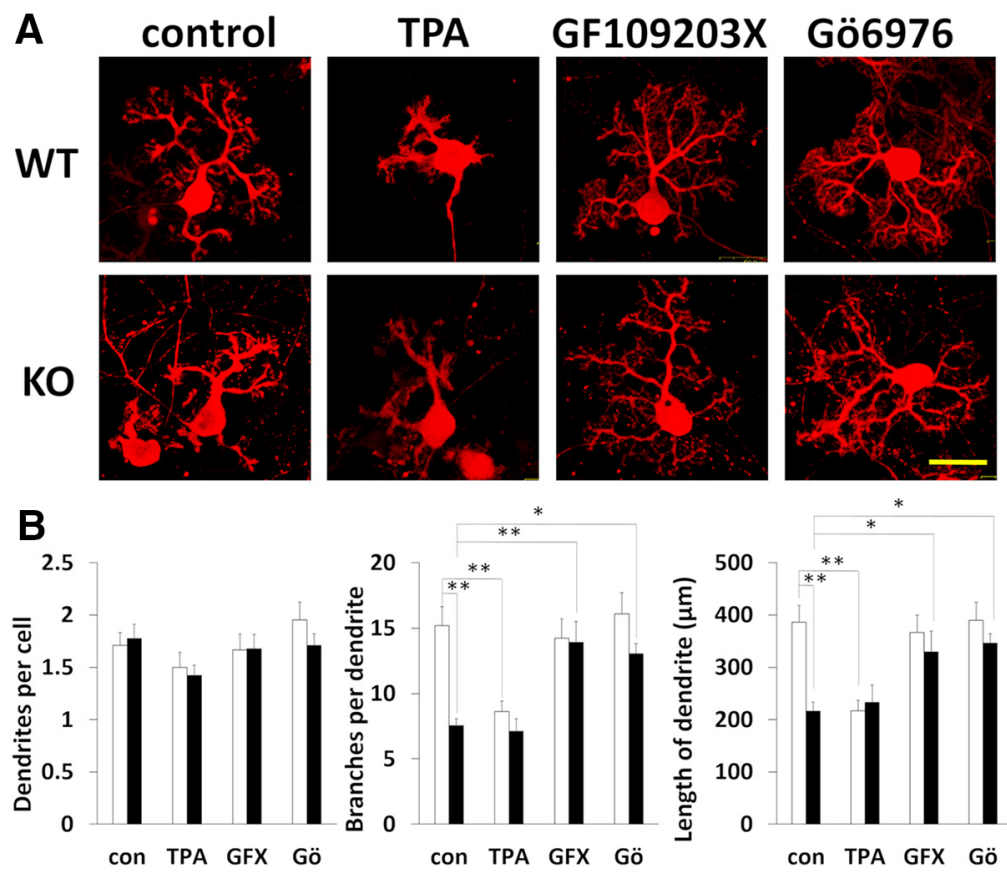

Figure 5. Effects of a PKC inhibitor on the dendritic development of primary cultured Purkinje cells. A, Purkinje cells from WT and DGK $\gamma$ KO mice were cultured for DIV21. The cells were treated with the PKC activator TPA, the panPKC inhibitor GF109203X (GFX) and the cPKC inhibitor Gö6976 (Gö) for the final $3 \mathrm{~d}$. After fixation, the cells were immunostained with an anti-calbindin antibody. Scale bar: $50 \mu \mathrm{m}$. $\boldsymbol{B}$, A comparison of the number of dendrites and branches and the total length of primary cultured Purkinje cells from WT and DGK $\gamma$ KO mice (WT, control (con): $n=31$, TPA: $n=22$, GFX: $n=27$, Gö: $n=22$; KO, con: $n=31$, TPA: $n=26$, GFX: $n=27$, Gö: $n=24) ; * p<0.05$, ** $p<0.01$, followed by Tukey's multiple comparisons test. Data are expressed as mean \pm SEM.

in a dose-dependent manner, but not the autophosphorylation of PKC $\alpha$ ((Fig. 7A; PKC $\gamma, 20 \mu \mathrm{M}: p=0.99,50 \mu \mathrm{M}$ : $p=0.21,100 \mu \mathrm{M}: p=0.47 ; \operatorname{PKC} \alpha, 20 \mu \mathrm{M}: p=0.046,50$ $\mu \mathrm{M}: p=0.027,100 \mu \mathrm{M}: p=0.0012$, Dunnett's test). Then, we also investigated the inhibitory effect of Scu on PKC $\gamma$ activity in cerebellar slices from DGK $\gamma$ KO mice. Scu $(100 \mu \mathrm{M})$ normalized the upregulated PKC $\gamma$ activity seen in DGK $\gamma$ KO mice to WT levels, but it had no significant effect on $\mathrm{PKC} \alpha$ activity (Fig. 7B; PKC $\gamma, \mathrm{KO}$ : $p=0.0059,20 \mu \mathrm{m}: p=0.0025$, Dunnett's test). These results suggest that Scu can be used as a PKC $\gamma$ inhibitor. Finally, to investigate the effect of a PKC $\gamma$ inhibitor on impaired LTD in DGK $\gamma$ KO mice, we added Scu to the extracellular solution when we measured LTD. As expected, Scu rescued the impairment of LTD in DGK $\gamma$ KO mice (Fig. 7C,D; WT-KO: $p=0.00,002$; KO-KO+Scu: $p=0.00,017$, Tukey's multiple comparison test). These results indicate that the impaired LTD in DGK $\gamma$ KO mice is dependent on PKC $\gamma$ activation in the basal state.

\section{Rescue effect of DGK $\gamma$ on the impairment of motor coordination}

Finally, we performed a rescue experiment using the FLP-FRT recombination system. As shown in Figure $8 A$, the cassette was inserted into DGK $\gamma$ KO mice $(\mathrm{tm} 1 \mathrm{a} /$ tm1a), and we eliminated the cassette by mating DGK $\gamma$ $\mathrm{KO}$ mice with FLP mice. Recombination was confirmed by PCR (Fig. $8 B$ ), and the recovery of DGK $\gamma$ in the cerebrum and cerebellum of tm1c/tm1c (1c) mice was confirmed by Western blotting (Fig. 8C). The rotarod and beam tests showed that the motor coordination of the 1c mice was normal (Fig. $8 D, E ; * p<0.05, * * p<0.01$; Tukey's multiple comparison test), suggesting the importance of DGK $\gamma$ for motor coordination.

\section{Discussion}

DGK $\gamma$ and PKC $\gamma$ are abundantly expressed in cerebellar Purkinje cells, and the functional correlation between these kinases is important for cerebellar motor coordination and the dendritic development of Purkinje cells. In this study, we investigated the function of DGK $\gamma$ in cerebellar motor coordination and related molecular mechanism using newly developed DGK $\gamma \mathrm{KO}$ mice. Cerebellar motor coordination was impaired in DGK $\gamma \mathrm{KO}$ mice most likely due to the loss of LTD and the impairment in the dendritic development of Purkinje cells. Our results suggest that DGK $\gamma$ contributes to cerebellar motor coordination through the regulation of LTD and the dendritic development of Purkinje cells through the regulation of PKC $\gamma$ activity.

To clarify the mechanism underlying the impairment of LTD in DGK $\gamma$ KO mice, we investigated the activity of $\mathrm{PKC} \alpha$ because it is responsible for inducing LTD through the phosphorylation of GluR2 S880 (Leitges et al., 2004). However, PKC $\alpha$ activation in the cerebellum was not detected. We also checked the phosphorylation of the S880 residue of GluR2, and found that the phosphorylation of GluR2 in the cerebellum of DGK $\gamma$ KO mice was not changed compared with that in the cerebellum of WT 
A





C
B



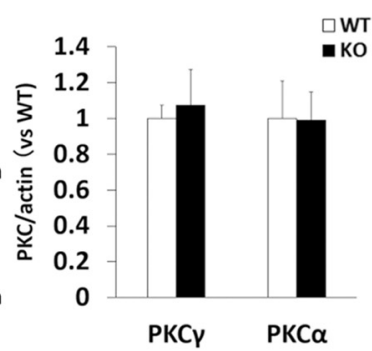

D
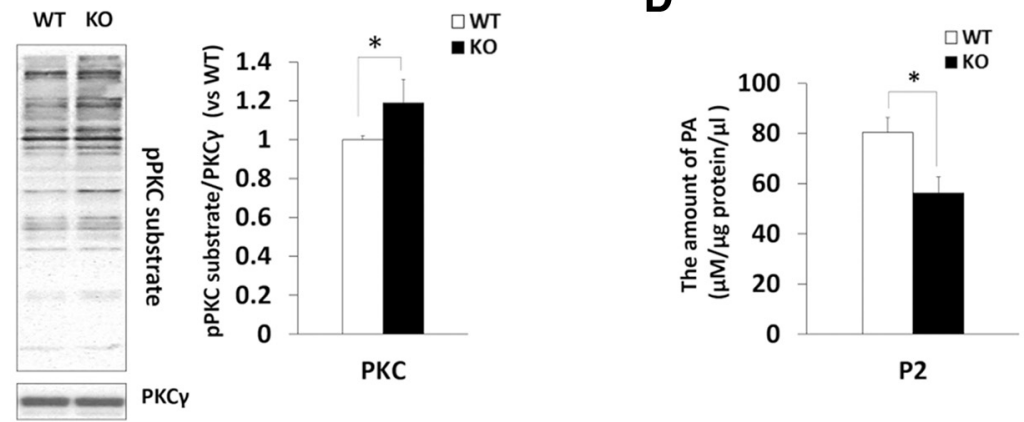

Figure 6. Upregulation of PKC activity in the cerebellum of DGK $\gamma$ KO mice. $\boldsymbol{A}-\boldsymbol{C}$, Cerebellar lysates from WT and DGK $\gamma$ KO mice were subjected to Western blotting and probed with anti-PKC $\gamma$, anti-PKC $\alpha$, anti-phospho-PKC $\gamma$ and anti-phospho-PKC $\alpha$, anti$\beta$-actin, and anti-PKC substrate antibodies. Quantification of the autophosphorylation and expression levels of PKC $\gamma$ as well as PKC $\alpha$ and PKC activity was performed by ImageJ. A, Phosphorylation of PKC $\gamma$ and PKC $\alpha$ was normalized to the PKC $\gamma$ and PKC $\alpha$ expression levels. B, Expression levels of PKC $\gamma$ and $\mathrm{PKC} \alpha$ were normalized to the expression level of the loading control ( $\beta$-actin). $\boldsymbol{C}$, Phosphorylation of the PKC substrate was normalized to the PKC $\gamma$ expression level. The ratio of the phosphorylation of PKC $\gamma$, $\mathrm{PKC} \alpha$, and PKC substrate to the expression levels of PKC $\gamma$ and PKC $\alpha$ to WT was plotted (PKC $\gamma: n=3 ; \mathrm{PKC} \alpha: n=3$; PKC substrate: $n=4$ ); $* p<0.05$, followed by Student's $t$ test. $\boldsymbol{D}$, The amount of PA in the P2 (crude synaptosomal membrane) fraction of WT and DGK $\gamma$ KO mice was measured by an enzymatic method $(n=4) ; * p<0.05$, followed by Student's $t$ test. Data are expressed as mean \pm SEM.

mice (data not shown), confirming that PKC $\alpha$ was not upregulated in the cerebellum in the basal state. On the other hand, PKC $\gamma$ was activated in the cerebellum of DGK $\gamma$ KO mice. Why only PKC $\gamma$ was upregulated when both PKC $\gamma$ and PKC $\alpha$ can be activated by DG and $\mathrm{Ca}^{2+}$. This may have been because PKC $\gamma$ but not PKC $\alpha$ can be activated by $D G$ at a basal intracellular $\mathrm{Ca}^{2+}$ concentration (Kohout et al., 2002; Ananthanarayanan et al., 2003). Another possibility is the mutual regulation of DGK $\gamma$ and PKC $\gamma$; DGK $\gamma$ and PKC $\gamma$ directly interact, and the phosphorylation of DGK $\gamma$ by PKC $\gamma$ upregulates DGK $\gamma$ activity (Yamaguchi et al., 2006). In addition, DGK $\gamma$ accelerates the retranslocation of PKC $\gamma$ from the membrane to the cytoplasm (Shirai et al., 2000), indicating that DGK $\gamma$ and PKC $\gamma$ mutually regulate each other's activity and that DGK $\gamma$ negatively regulates PKC $\gamma$ activity under basal conditions. There have been several reports on the mutual regulation of other DGKs and PKCs (Topham et al., 1998; Imai et al., 2004; Van Baal et al., 2005) and the importance of these regulator mechanisms for synaptic plasticity (Lee et al., 2016). For example, DGK $\zeta$ directly interacts with PKC $\alpha$ and lowers PKC $\alpha$ activity by reducing DG levels in the basal state (Luo et al., 2003). An increase in the DG levels activates PKC $\alpha$, which phosphorylates $\mathrm{DGK} \zeta$, resulting in the dissociation of $\mathrm{PKC} \alpha$ and $\mathrm{DGK} \zeta$. The spatial regulation of $\mathrm{PKC} \alpha$ activity by DGK $\zeta$ contributes to cerebellar LTD (Lee et al., 2015). Therefore, PKC $\alpha$ in the cerebellum of DGK $\gamma$ KO mice may be inhibited by its interaction with DGK $\zeta$. Furthermore, PKCs have different sensitivities and dependencies on DG species (Kamiya et al., 2016), and each DGK utilizes different DG species (Sakane et al., 2018). Taken together, DGK $\gamma$ deficiency may upregulate PKC $\gamma$ but not $\operatorname{PKC} \alpha$. However, the upregulation of both $\mathrm{PKC} \alpha$ and $\mathrm{PKC} \gamma$ is likely induced by an increase of DG levels through DGK $\gamma$ deficiency. Indeed, the PKC $\gamma$ inhibitor Scu rescued impaired cerebellar LTD in DGK $\gamma$ KO mice. These results suggest that PKC $\gamma$ upregulation in the basal state is involved in the impairment of LTD in DGK $\gamma$ KO mice and that DGK $\gamma$ is responsible for lowering PKC $\gamma$ activity at LTD stimulation.

In this case, a new question of how upregulated $\mathrm{PKC} \gamma$ impairs cerebellar LTD has arisen. Transient receptor potential canonical channel 3 (TRPC3) may be a key molecule. TRPC3 is abundantly expressed in Purkinje cells, and PKC $\gamma$ negatively regulates TRPC 3 activity and extracellular $\mathrm{Ca}^{2+}$ influx (Adachi et al., 2008). TRPC3 KO mice show dysfunction of motor coordination, and the inhibition of TRPC3 impairs cerebellar LTD (Hartmann et al., 2008; Kim, 2013). PKC $\gamma$ negatively regulates TRPC3 activity and extracellular $\mathrm{Ca}^{2+}$ influx through TRPC3 (Adachi et al., 2008). Based on these facts, we speculate that the inactivation of TRPC3 by upregulated PKC $\gamma$ may inhibit $\mathrm{Ca}^{2+}$ influx, resulting in PKC $\alpha$ inactivation during LTD stimulation. LTD stimulation increases the DG levels and 
A

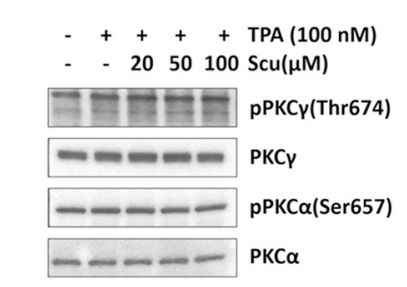

B



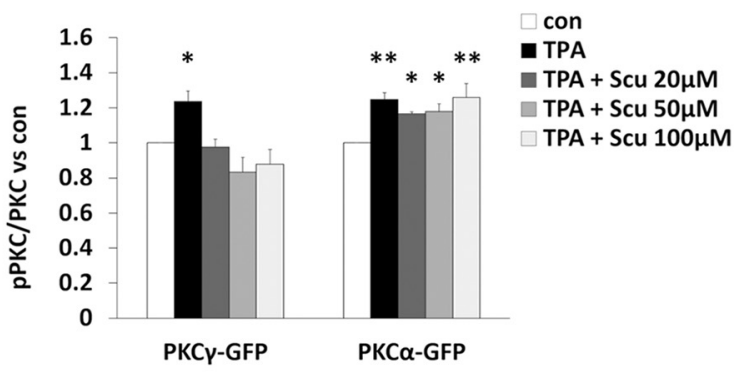


D



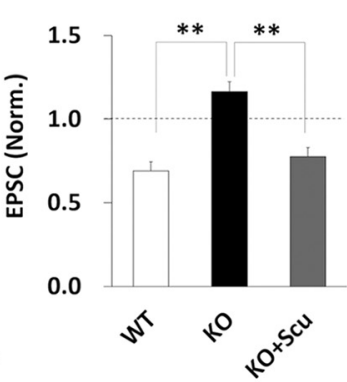

Figure 7. Rescue of impaired LTD in DGK $\gamma$ KO mice by a PKC $\gamma$ inhibitor. $\boldsymbol{A}$, COS-7 cells overexpressing PKC $\gamma$-GFP or PKC $\alpha$-GFP were cultured for $48 \mathrm{~h}$. The cells were treated with TPA (100 nM) for $30 \mathrm{~min}$ after preincubation with or without scutellarin (Scu; 20, 50 , or $100 \mu \mathrm{m}$ ) for $30 \mathrm{~min}$. The lysates from the cells were subjected to Western blotting and probed with anti-phospho-PKC $\gamma$, antiPKC $\gamma$, anti-phospho-PKC $\alpha$, and anti-PKC $\alpha$ antibodies. Quantification of the autophosphorylation of PKC $\gamma$ and PKC $\alpha$ was performed by ImageJ. The phosphorylation levels of PKC $\gamma$ and PKC $\alpha$ were normalized to the PKC $\gamma$ and PKC $\alpha$ expression levels. The ratio of the phosphorylation of PKC $\gamma$ and PKC $\alpha$ to that in the control was plotted (PKC $\gamma$-GFP: $n=6$; PKC $\alpha$-GFP: $n=6$ ); $* p<0.05$, $* * p<0.01$ (vs control), followed by Dunnett's test. $\boldsymbol{B}$, Acute cerebellar slices from WT and DGK $\gamma$ KO mice were incubated with or without Scu (20 or $100 \mu \mathrm{M})$ for $1 \mathrm{~h}$. Lysates from the slices were subjected to Western blotting as described in $\boldsymbol{A}$ (PKC $\gamma: n=3$; PKC $\alpha: n=3$ ); $* p<0.05, * * p<0.01$ (vs WT), followed by Dunnett's test. $\boldsymbol{C}$. Changes in the PF-EPSC amplitude before and after the CJS of PF $(1 \mathrm{~Hz}, 300 \mathrm{~s})$ with depolarization applied at time 0. A PKC $\gamma$ inhibitor Scu $(100 \mu \mathrm{M})$ was added to the extracellular solution prior to stimulation. The PF-EPSC amplitude was normalized to the mean over 10 min before CJS (WT: $n=8 ; \mathrm{KO}: n=8$; KO+Scu: $n=7$ ). Sample traces immediately before (1) and $30 \mathrm{~min}$ after (2) CJS. $\boldsymbol{D}$. Average PF-EPSC amplitude over the 21- to 30 -min period after CJS; $* * p<0.01$, followed by Tukey's multiple comparisons test. Data are expressed as mean \pm SEM.

the intracellular $\mathrm{Ca}^{2+}$ concentration through the mGluR1 cascade and depolarization (Ito, 2002); however, the latter but not the former controls PKC $\alpha$ activation during the induction of cerebellar LTD (Tsuruno and Hirano, 2007). In other words, the $\mathrm{Ca}^{2+}$ influx into Purkinje cells in DGK $\gamma$ $\mathrm{KO}$ mice is not enough to activate $\mathrm{PKC} \alpha$ and release $\mathrm{PKC} \alpha$ and DGK $\zeta$. This speculation does not deny the involvement of PKC $\alpha$ in cerebellar LTD. However, to confirm this hypothesis, additional experiments are needed.

Our results also showed that impairments in the dendritic development of Purkinje cells in DGK $\gamma$ KO mice and the cPKC inhibitor Gö6976 normalized the dendrite retraction of Purkinje cells in DGK $\gamma$ KO mice to WT levels, suggesting that $\mathrm{CPKC}$ activity mainly functions in the dendritic development in Purkinje cells. In particular, the activity of PKC $\gamma$ is likely involved in the impairment of Purkinje cell branching in DGK $\gamma$ KO mice because the activation of PKC $\gamma$ was confirmed. Indeed, the dendrites of Purkinje cells in PKC $\gamma$ KO mice are enlarged, whereas those in $\mathrm{PKC} \alpha \mathrm{KO}$ mice are not changed compared with those in WT mice (Schrenk et al., 2002; Gundlfinger et al., 2003). Furthermore, DGK $\gamma$ activity was necessary for the development of neurites in Neuro-2A cells (data not shown). Taken together, these results suggest that DGK $\gamma$ contributes to the dendritic development of Purkinje cells through the regulation of $\mathrm{PKC} \gamma$ activity. In addition, 
A

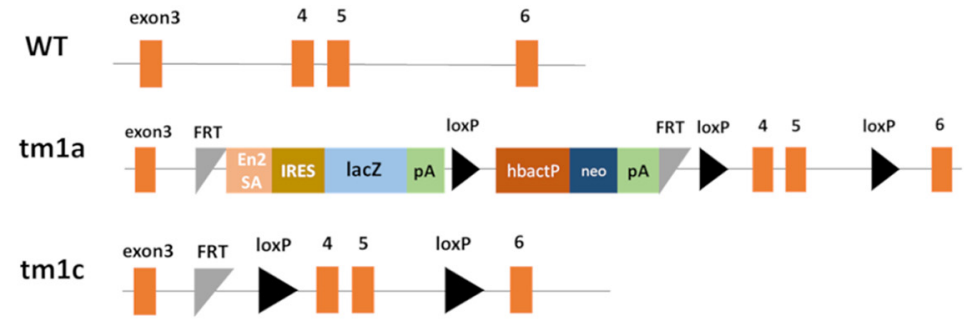

B

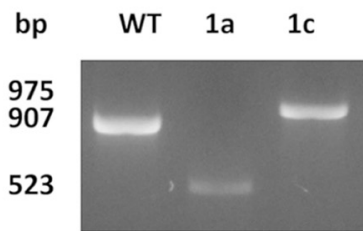

D

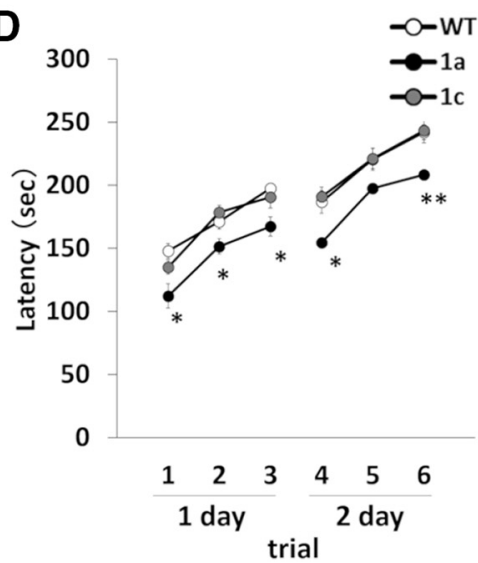

C Cerebrum Cerebellum

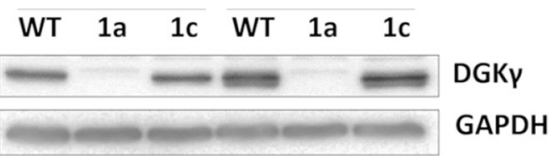

E



Figure 8. Rescue of motor coordination in DGK $\gamma$ floxed (tm1c) mice. $\boldsymbol{A}, \mathrm{WT}$, tm1a, and tm1c alleles. $\boldsymbol{B}$, Typical results of PCR genotyping. Bands at 975, 907, and 523 bp were expected for the tm1c, WT, and tm1a alleles, respectively. C, Cerebral and cerebellar lysates from WT, tm1a (1a), and tm1c (1c) mice were subjected to Western blotting and probed with anti-DGK $\gamma$ and anti-GAPDH antibodies. $\boldsymbol{D}$, Motor coordination of WT, tm1a (1a), and tm1c (1c) mice was assessed by the accelerating rotarod test (WT: $n=14$; 1a: $n=15$; 1c: $n=15$ ); $* p<0.05, * * p<0.01$, followed by Tukey's multiple comparisons test. $\boldsymbol{E}$, Motor coordination of WT, tm1a (1a), and tm1c (1c) mice was assessed by the number of hind paw slips in the beam test (WT: $n=5 ; 1 \mathrm{a}: n=5 ; 1 \mathrm{c}: n=3) ; * p<0.05$, followed by Tukey's multiple comparisons test. Data are expressed as mean \pm SEM.

PKC $\gamma$ regulates spinogenesis and the morphology of the spines of distal dendrites through the phosphorylation of CaMKII $\beta$ (Sugawara et al., 2017). Purkinje cells in DGK $\gamma$ $\mathrm{KO}$ mice showed retracted distal dendrites, but the basic electrophysiological properties of PFs were normal, indicating that DGK $\gamma \mathrm{KO}$ mice retained basic excitatory circuitry. On the other hand, morphologic abnormalities in spines of Purkinje cells cause impairments in motor coordination (Sugawara et al., 2013). Accordingly, morphologic abnormalities in spines of Purkinje cells may also contribute to cerebellar motor dysfunction in DGK $\gamma \mathrm{KO}$ mice, although further study is necessary.

Cerebellar motor coordination was impaired not only by cerebellar LTD and alterations in the dendritic morphology of Purkinje cells but also by the disruption of refined motor program transmission through multiple CF innervation. A single Purkinje cell originally exhibits multiple CF innervation; however, it exhibits mono CF innervation as it grows due to pruning (Watanabe and Kano, 2011). CFs transmit signals to Purkinje cells to refine the motor program to prevent incorrect motor programming, resulting in the suppression of PF-EPSCs involved in incorrect motor programming and the induction of cerebellar LTD (Welsh et al., 1995). Previous reports have indicated the importance of PKC $\gamma$ in CF innervation; multiple CF innervation has been detected in mature PKC $\gamma$ KO mice (Kano et al., 1995), and a constitutively active PKC $\gamma$ mutant (S119P) also causes multiple CF innervation (Shuvaev et al., 2011). However, we demonstrated that the CF innervation of Purkinje cells in DGK $\gamma \mathrm{KO}$ mice was normal, although PKC $\gamma$ activation was detected in the cerebellum. This is not surprising because the loss of function of PKC $\gamma$ seems to be critical for CF innervation. Indeed, the membrane residence time of the PKC $\gamma$ mutant (S119P) is shorter due to a lack of binding with DG induced by the mutation in the $\mathrm{C} 1$ domain; that is, the PKC $\gamma$ mutant does not exhibit activity in the membrane (Adachi et al., 2008). Alternatively, PKC $\gamma$ activity in the CFs of DGK $\gamma$ KO mice may be normal because CFs do not express DGK $\gamma$, even in WT mice.

Thus far, we have focused on PKC to understand the molecular mechanism underlying the impairment of 


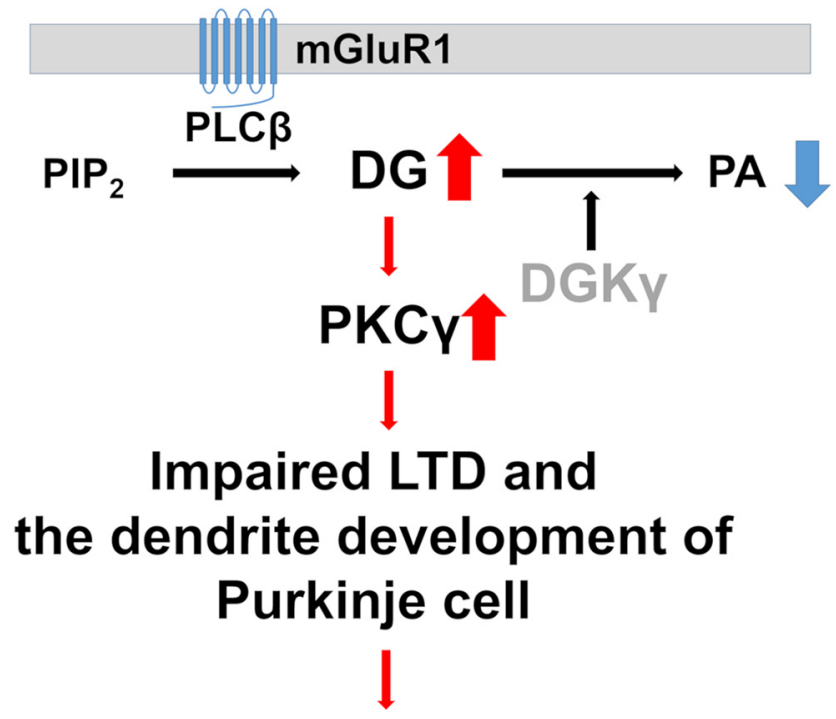

Motor dyscoordination

Figure 9. Schematic illustration of motor dyscoordination in DGK $\gamma$ KO mice. DGK $\gamma$ deficiency decreases PA levels and increases DG levels. Increased DG constitutively activates PKC $\gamma$, resulting in impaired LTD and the dendritic development of Purkinje cells. These alterations are manifested as motor dyscoordination in DGK $\gamma$ KO mice.

cerebellar LTD and dendritic development of Purkinje cells in DGK $\gamma \mathrm{KO}$ mice; these processes are activated by DG but we also studied PA. Our results showed that PA was decreased in the cerebellum of DGK $\gamma \mathrm{KO}$ mice, suggesting that aberrant PA-mTOR signaling has some influence on impaired motor coordination in DGK $\gamma$ KO mice. PA, which is generated by DGK, activates mTOR (AvilaFlores et al., 2005), which is involved in neurodevelopment and neuropsychiatric disorders (Costa-Mattioli and Monteggia, 2013; Bockaert and Marin, 2015). mTOR forms two distinct complexes, namely, mTORC1 and mTORC2, which are distinguished by their specific components and sensitivity to rapamycin (Laplante and Sabatini, 2012). Recent studies have revealed that mTORC1 and mTORC2 share a few functions but exhibit many distinct functions in Purkinje cells (Thomanetz et al., 2013; Angliker et al., 2015). A deficiency in mTORC2 results in multiple CF innervation but does not affect cerebellar LTD. A deficiency in mTORC1 results in a progressive loss of Purkinje cells, while its involvement in cerebellar LTD remains unknown. In other words, the dendritic atrophy of Purkinje cells induced by a deficiency in mTORC1 or mTORC2 is similar to that observed in DGK $\gamma$ KO mice, although DGK $\gamma$ KO mice do not exhibit the multiple CF innervation seen in mTORC2 KO mice and the loss of Purkinje cells seen in mTORC1 $\mathrm{KO}$ mice. Therefore, it is possible that PA-mTOR signaling also interferes with the phenotype of DGK $\gamma$ KO mice.

In summary (Fig. 9), the increase in DG levels caused by DGK $\gamma$ deficiency aberrantly activates PKC $\gamma$ Activated PKC $\gamma$ impairs LTD and the dendritic development of Purkinje cells, resulting in motor dyscoordination in DGK $\gamma$
KO mice. We showed for the first time the importance of DGK $\gamma$ in cerebellar LTD and the dendritic development of Purkinje cells through the regulation of PKC $\gamma$ activity and its contribution to cerebellar motor coordination.

\section{References}

Adachi N, Oyasu M, Taniguchi T, Yamaguchi Y, Takenaka R, Shirai Y, Saito N (2005) Immunocytochemical localization of a neuronspecific diacylglycerol kinase $\beta$ and $\gamma$ in the developing rat brain. Brain Res Mol 139:288-299.

Adachi N, Kobayashi T, Takahashi H, Kawasaki T, Shirai Y, Ueyama T, Matsuda T, Seki T, Sakai N, Saito N (2008) Enzymological analysis of mutant protein kinase Cgamma causing spinocerebellar ataxia type 14 and dysfunction in $\mathrm{Ca} 2+$ homeostasis. J Biol Chem 283:19854-19863.

Almena M, Mérida I (2011) Shaping up the membrane: Diacylglycerol coordinates spatial orientation of signaling. Trends Biochem Sci 36:593-603.

Ananthanarayanan B, Stahelin RV, Digman MA, Cho W (2003) Activation mechanisms of conventional protein kinase $\mathrm{C}$ isoforms are determined by the ligand affinity and conformational flexibility of their $\mathrm{C} 1$ domains. J Biol Chem 278:46886-46894.

Angliker N, Burri M, Zaichuk M, Fritschy JM, Rüegg MA (2015) mTORC1 and mTORC2 have largely distinct functions in Purkinje cells. Eur J Neurosci 42:2595-2612. ]

Avila-Flores A, Santos T, Rincón E, Mérida I (2005) Modulation of the mammalian target of rapamycin pathway by diacylglycerol kinaseproduced phosphatidic acid. J Biol Chem 280:10091-10099.

Bockaert J, Marin P (2015) mTOR in brain physiology and pathologies. Physiol Rev 95:1157-1187.

Chen C, Kano M, Abeliovich A, Chen L, Bao S, Kim JJ, Hashimoto K, Thompson RF, Tonegawa S (1995) Impaired motor coordination correlates with persistent multiple climbing fiber innervation in PKC gamma mutant mice. Cell 83:1233-1242.

Costa-Mattioli M, Monteggia LM (2013) mTOR complexes in neurodevelopmental and neuropsychiatric disorders. Nat Neurosci 16:1537-1543.

Edwards FA, Konnerth A, Sakmann B, Takahashi T (1989) A thin slice preparation for patch clamp recordings from neurones of the mammalian central nervous system. Pflugers Arch 414:600-612.

Fang Y, Vilella-Bach M, Bachmann R, Flanigan A, Chen J (2001) Phosphatidic acid-mediated mitogenic activation of mTOR signaling. Science 294:1942-1945.

Fujihara Y, Kaseda K, Inoue N, Ikawa M, Okabe M (2013) Production of mouse pups from germline transmission-failed knockout chimeras. Transgenic Res 22:195-200.

Ghosh S, Strum JC, Sciorra VA, Daniel L, Bell RM (1996) Raf-1 kinase possesses distinct binding domains for phosphatidylserine and phosphatidic acid. Phosphatidic acid regulates the translocation of Raf-1 in 12-O-tetradecanoylphorbol-13-acetate-stimulated MadinDarby canine kidney cells. J Biol Chem 271:8472-8480.

Goto K, Kondo H (1999) Diacylglycerol kinase in the central nervous system-molecular heterogeneity and gene expression. Chem Phys Lipids 98:109-117.

Gu Z, Liu W, Yan Z (2009) $\beta$-amyloid impairs AMPA receptor trafficking and function by reducing $\mathrm{Ca} 2+/$ calmodulin-dependent protein kinase II synaptic distribution. J Biol Chem 284:10639-10649.

Gundlfinger A, Kapfhammer JP, Kruse F, Leitges M, Metzger F (2003) Different regulation of Purkinje cell dendritic development in cerebellar slice cultures by protein kinase Calpha and -beta. $\mathrm{J}$ Neurobiol 57:95-109.

Hartmann J, Dragicevic E, Adelsberger H, Henning HA, Sumser M, Abramowitz J, Blum R, Dietrich A, Freichel M, Flockerzi V, Birnbaumer L, Konnerth A (2008) TRPC3 channels are required for synaptic transmission and motor coordination. Neuron 59:392398.

Hirai $H$ (2018) Protein kinase $C$ in the cerebellum: Its significance and remaining conundrums. Cerebellum 17:23-27. 
Imai SI, Kai M, Yamada K, Kanoh H, Sakane F (2004) The plasma membrane translocation of diacylglycerol kinase delta1 is negatively regulated by conventional protein kinase C-dependent phosphorylation at Ser-22 and Ser-26 within the pleckstrin homology domain. Biochem J 382:957-966.

Ito $M(2002)$ The molecular organization of cerebellar long-term depression. Nat Rev Neurosci 3:896-902.

Jones DR, Sanjuan MA, Mérida I (2000) Type lalpha phosphatidylinositol 4-phosphate 5-kinase is a putative target for increased intracellular phosphatidic acid. FEBS Lett 476:160-165.

Kakizawa S, Yamasaki M, Watanabe M, Kano M (2000) Critical period for activity-dependent synapse elimination in developing cerebellum. J Neurosci 20:4954-4961.

Kakizawa S, Yamada K, lino M, Watanabe M, Kano M (2003) Effects of insulin-like growth factor I on climbing fibre synapse elimination during cerebellar development. Eur J Neurosci 17:545-554.

Kakizawa S, Yamazawa T, Chen Y, Ito A, Murayama T, Oyamada H, Kurebayashi N, Sato O, Watanabe M, Mori N, Oguchi K, Sakurai T, Takeshima H, Saito N, lino M (2012) Nitric oxide-induced calcium release via ryanodine receptors regulates neuronal function. EMBO J 31:417-428.

Kamiya Y, Mizuno S, Komenoi S, Sakai H, Sakane F (2016) Activation of conventional and novel protein kinase $\mathrm{C}$ isozymes by different diacylglycerol molecular species. Biochem Biophys Rep 7:361-366.

Kano M, Hashimoto K, Chen C, Abeliovich A, Aiba A, Kurihara H, Watanabe M, Inoue Y, Tonegawa S (1995) Impaired synapse elimination during cerebellar development in PKC gamma mutant mice. Cell 83:1223-1231.

Kano M, Hashimoto K, Kurihara $\mathrm{H}$, Watanabe $\mathrm{M}$, Inoue $\mathrm{Y}$, Aiba A, Tonegawa S (1997) Persistent multiple climbing fiber innervation of cerebellar Purkinje cells in mice lacking mGluR1. Neuron 18:71-79.

Kano M, Hashimoto K, Watanabe M, Kurihara H, Offermanns S, Jiang H, Wu Y, Jun K, Shin H-S, Inoue Y, Simon MI, Wu D (1998) Phospholipase C4beta is specifically involved in climbing fiber synapse elimination in the developing cerebellum. Proc Natl Acad Sci USA 95:15724-15729.

Kano T, Kouzuki T, Mizuno S, Ueda S, Yamanoue M, Sakane F, Saito $N$, Shirai $Y(2014)$ Both the C1 domain and a basic amino acid cluster at the C-terminus are important for the neurite and branch induction ability of DGK $\beta$. Biochem Biophys Res Commun 447:89-94.

Kanoh H, Yamada K, Sakane F (2002) Diacylglycerol kinases: Emerging downstream regulators in cell signaling systems. J Biochem 131:629-633.

Kim SJ (2013) TRPC3 channel underlies cerebellar long-term depression. Cerebellum 12:334-337.

Kohout SC, Corbalán-García S, Torrecillas A, And J-F, Falke JJ (2002) C2 domains of protein kinase $\mathrm{C}$ isoforms $\alpha, \beta$, and $\gamma$ : Activation parameters and calcium stoichiometries of the membrane-bound state. Biochemistry 41:11411-11424.

Laplante M, Sabatini DM (2012) mTOR signaling in growth control and disease. Cell 149:274-293.

Lee D, Yamamoto Y, Kim E, Tanaka-Yamamoto K (2015) Functional and physical interaction of diacylglycerol kinase $\zeta$ with protein kinase $\mathrm{C} \alpha$ is required for cerebellar long-term depression. J Neurosci 35:15453-15465.

Lee D, Kim E, Tanaka-Yamamoto K (2016) Diacylglycerol kinases in the coordination of synaptic plasticity. Front cell Dev Biol 4:92.

Leitges M, Kovac J, Plomann M, Linden DJ (2004) A unique PDZ ligand in PKCalpha confers induction of cerebellar long-term synaptic depression. Neuron 44:585-594.

Limatola C, Schaap D, Moolenaar WH, van Blitterswijk WJ (1994) Phosphatidic acid activation of protein kinase C-4 overexpressed in COS cells: Comparison with other protein kinase $\mathrm{C}$ isotypes and other acidic lipids. Biochem J 304:1001-1008.

Llano I, Marty A, Armstrong CM, Konnerth A (1991) Synaptic- and agonist-induced excitatory currents of Purkinje cells in rat cerebellar slices. J Physiol 434:183-213.

Luo B, Prescott SM, Topham MK (2003) Association of diacylglycerol kinase zeta with protein kinase $C$ alpha: Spatial regulation of diacylglycerol signaling. J Cell Biol 160:929-937.
Metzger F, Kapfhammer JP (2000) Protein kinase C activity modulates dendritic differentiation of rat Purkinje cells in cerebellar slice cultures. Eur J Neurosci 12:1993-2005.

Metzger F, Kapfhammer JP (2003) Protein kinase C: Its role in activity-dependent Purkinje cell dendritic development and plasticity. Cerebellum 2:206-214.

Morita S, Ueda K, Kitagawa S (2009) Enzymatic measurement of phosphatidic acid in cultured cells. J Lipid Res 50:1945-1952.

Offermanns S, Hashimoto K, Watanabe M, Sun W, Kurihara H, Thompson RF, Inoue Y, Kano M, Simon MI (1997) Impaired motor coordination and persistent multiple climbing fiber innervation of cerebellar Purkinje cells in mice lacking Galphaq. Proc Natl Acad Sci USA 94:14089-14094.

Raben DM, Tu-Sekine B (2011) Regulation and roles of neuronal diacylglycerol kinases: A lipid perspective. Crit Rev Biochem Mol Biol 46:353-364.

Sakane F, Imai S, Kai M, Yasuda S, Kanoh H (2007) Diacylglycerol kinases: Why so many of them? Biochim Biophys Acta 1771:793806.

Sakane F, Mizuno S, Takahashi D, Sakai H (2018) Where do substrates of diacylglycerol kinases come from? Diacylglycerol kinases utilize diacylglycerol species supplied from phosphatidylinositol turnover-independent pathways. Adv Biol Regul 67:101-108.

Schrenk K, Kapfhammer JP, Metzger F (2002) Altered dendritic development of cerebellar Purkinje cells in slice cultures from protein kinase C $\gamma$-deficient mice. Neuroscience 110:675-689.

Seki T, Shimahara T, Yamamoto K, Abe N, Amano T, Adachi N, Takahashi H, Kashiwagi K, Saito N, Sakai N (2009) Mutant gammaPKC found in spinocerebellar ataxia type 14 induces aggregate-independent maldevelopment of dendrites in primary cultured Purkinje cells. Neurobiol Dis 33:260-273.

Shirai Y, Saito N (2014) Diacylglycerol kinase as a possible therapeutic target for neuronal diseases. J Biomed Sci 21:28.

Shirai Y, Segawa S, Kuriyama M, Goto K, Sakai N, Saito N (2000) Subtype-specific translocation of diacylglycerol kinase $\alpha$ and $\gamma$ and its correlation with protein kinase C. J Biol Chem 275:24760-24766.

Shuvaev AN, Horiuchi H, Seki T, Goenawan H, Irie T, lizuka A, Sakai $\mathrm{N}$, Hirai $\mathrm{H}$ (2011) Mutant PKC $\gamma$ in spinocerebellar ataxia type 14 disrupts synapse elimination and long-term depression in Purkinje cells in vivo. J Neurosci 31:14324-14334.

Skarnes WC, Rosen B, West AP, Koutsourakis M, Bushell W, lyer V, Mujica AO, Thomas M, Harrow J, Cox T, Jackson D, Severin J, Biggs P, Fu J, Nefedov M, De Jong PJ, Stewart AF, Bradley A (2011) A conditional knockout resource for the genome-wide study of mouse gene function. Nature 474:337-344.

Su Y, Liu W, Ma L, Liu X, Liu Z, Zhu B (2012) Scutellarin inhibits translocation of protein kinase $C$ in diabetic thoracic aorta of the rat. Clin Exp Pharmacol Physiol 39:136-140.

Sugawara T, Hisatsune C, Le TD, Hashikawa T, Hirono M, Hattori M, Nagao S, Mikoshiba K (2013) Type 1 inositol trisphosphate receptor regulates cerebellar circuits by maintaining the spine morphology of Purkinje cells in adult mice. J Neurosci 33:12186-12196.

Sugawara T, Hisatsune C, Miyamoto H, Ogawa N, Mikoshiba K (2017) Regulation of spinogenesis in mature Purkinje cells via mGluR/PKC-mediated phosphorylation of $\mathrm{CaMKII} \beta$. Proc Natl Acad Sci USA 114:E5256-E5265.

Thomanetz V, Angliker N, Cloëtta D, Lustenberger RM, Schweighauser M, Oliveri F, Suzuki N, Rüegg MA (2013) Ablation of the mTORC2 component rictor in brain or Purkinje cells affects size and neuron morphology. J Cell Biol 201:293-308.

Topham MK, Prescott SM (1999) Mammalian diacylglycerol kinases, a family of lipid kinases with signaling functions. J Biol Chem 274:11447-11450.

Topham MK, Bunting M, Zimmerman GA, McIntyre TM, Blackshear PJ, Prescott SM (1998) Protein kinase C regulates the nuclear localization of diacylglycerol kinase-z. Nature 394:697-700.

Tsuruno S, Hirano T (2007) Persistent activation of protein kinase Calpha is not necessary for expression of cerebellar long-term depression. Mol Cell Neurosci 35:38-48. 
Ueda S, Tu-Sekine B, Yamanoue M, Raben DM, Shirai Y (2013) The expression of diacylglycerol kinase theta during the organogenesis of mouse embryos. BMC Dev Biol 13:35.

Van Baal J, De Widt J, Divecha N, Van Blitterswijk WJ (2005) Translocation of diacylglycerol kinase $\theta$ from cytosol to plasma membrane in response to activation of $\mathrm{G}$ protein-coupled receptors and protein kinase C. J Biol Chem 280:9870-9878.

van Blitterswijk WJ, Houssa B (2000) Properties and functions of diacylglycerol kinases. Cell Signal 12:595-605.

Watanabe M, Kano M (2011) Climbing fiber synapse elimination in cerebellar Purkinje cells. Eur J Neurosci 34:1697-1710.

Welsh JP, Lang EJ, Suglhara I, Llinás R (1995) Dynamic organization of motor control within the olivocerebellar system. Nature 374:453-457.
Xu W, Zha RP, Wang WY, Wang YP (2007) Effects of scutellarin on PKCgamma in PC12 cell injury induced by oxygen and glucose deprivation. Acta Pharmacol Sin 28:1573-1579.

Yamaguchi Y, Shirai Y, Matsubara T, Sanse K, Kuriyama M, Oshiro N, Yoshino K, Yonezawa K, Ono Y, Saito N (2006) Phosphorylation and up-regulation of diacylglycerol kinase $\gamma$ via its interaction with protein kinase C $\gamma$. J Biol Chem 281:31627-31637.

Yamazaki D, Miyata H, Funato Y, Fujihara Y, Ikawa M, Miki H (2016) The Mg 2+ transporter CNNM4 regulates sperm Ca 2+ homeostasis and is essential for reproduction. J Cell Sci 129:19401949.

Zucker RS, Regehr WG (2002) Short-term synaptic plasticity. Annu Rev Physiol 64:355-405. 